\title{
Fuel Cell Buses in U.S. Transit Fleets: Summary of Experiences and Current Status
}

Technical Report NREL/TP-560-41967

September 2007

L. Eudy

National Renewable Energy Laboratory

K. Chandler

Battelle

C. Gikakis

Federal Transit Administration
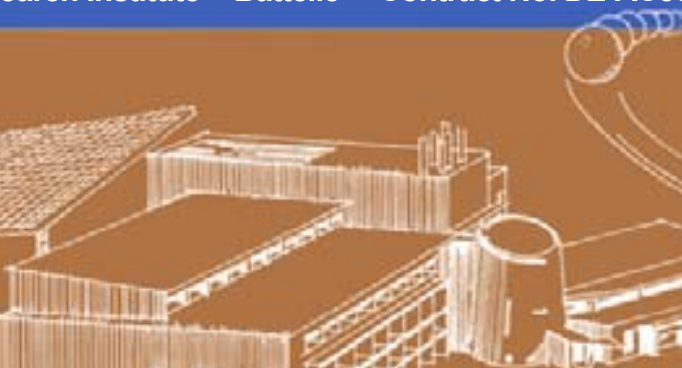


\section{Fuel Cell Buses in U.S. Transit Fleets: Summary of Experiences and Current Status}

L. Eudy

National Renewable Energy Laboratory

K. Chandler

Battelle

C. Gikakis

Federal Transit Administration

Prepared under Task No. H270.8200
Technical Report NREL/TP-560-41967

September 2007

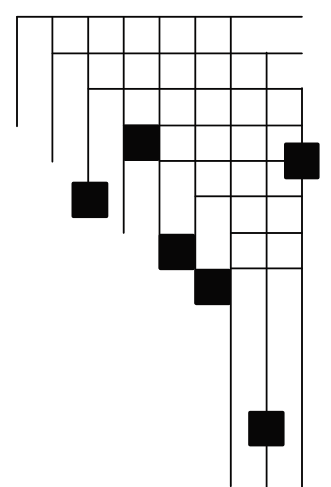




\section{NOTICE}

This report was prepared as an account of work sponsored by an agency of the United States government. Neither the United States government nor any agency thereof, nor any of their employees, makes any warranty, express or implied, or assumes any legal liability or responsibility for the accuracy, completeness, or usefulness of any information, apparatus, product, or process disclosed, or represents that its use would not infringe privately owned rights. Reference herein to any specific commercial product, process, or service by trade name, trademark, manufacturer, or otherwise does not necessarily constitute or imply its endorsement, recommendation, or favoring by the United States government or any agency thereof. The views and opinions of authors expressed herein do not necessarily state or reflect those of the United States government or any agency thereof.

Available electronically at http://www.osti.gov/bridge

Available for a processing fee to U.S. Department of Energy and its contractors, in paper, from:

U.S. Department of Energy

Office of Scientific and Technical Information

P.O. Box 62

Oak Ridge, TN 37831-0062

phone: 865.576 .8401

fax: 865.576 .5728

email: mailto:reports@adonis.osti.gov

Available for sale to the public, in paper, from:

U.S. Department of Commerce

National Technical Information Service

5285 Port Royal Road

Springfield, VA 22161

phone: 800.553.6847

fax: 703.605.6900

email: orders@ntis.fedworld.gov

online ordering: http://www.ntis.gov/ordering.htm 


\section{Acknowledgements}

This document includes results and experiences from several U.S. fuel cell bus evaluation projects. The active participation of our project partners is greatly appreciated. Contributors to this report included staff members of federal and state government agencies, manufacturing firms, and transit authorities. The authors especially thank the following:

Nico Bouwkamp, California Fuel Cell Partnership

Doug Byrne, Jaimie Levin, and Mallory Nestor-Brush, Alameda-Contra Costa Transit District

Lesley Crowell, Anna Gromis, and Gerhard Achtelik, California Air Resources Board

Polo Del Toro and Tommy Edwards, SunLine Transit Agency

Art Douwes, Santa Clara Valley Transportation Authority

Neil Flemmer and Paul Scott, ISE Corporation

John Garbak, U.S. Department of Energy

Kevin Harris, Hydrogenics Corporation

Walter Kulyk, U.S. Department of Transportation, Federal Transit Administration

Sandra Lajewski, Matthew Riley, and Mike Tosca, UTC Power

Byron Somerville and TJ Lawy, Ballard Power Systems Inc.

George Sverdrup and Keith Wipke, National Renewable Energy Laboratory 


\section{Table of Contents}

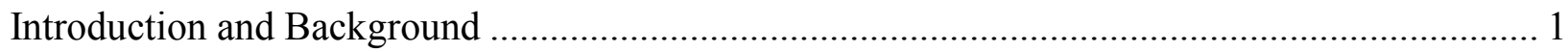

U.S. Fuel Cell Bus Demonstrations and Evaluations.............................................................. 3

DOE Fuel Cell and Hydrogen Powered Transit Bus Evaluations ............................................. 4

FTA Fuel Cell and Hydrogen-Powered Transit Bus Projects ................................................. 4

Why Develop Fuel Cell and Hydrogen Technology for Transit Buses? ……………................. 8

Regulation and Policy Drivers for Fuel Cell Buses ................................................................... 9

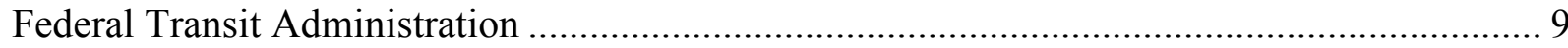

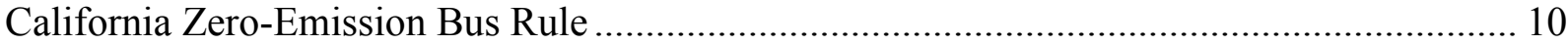

Other Factors That Could Impact U.S. Commercialization .................................................. 11

Development Path for New Transit Bus Technologies.............................................................. 12

Documented Fuel Cell Transit Bus Experience......................................................................... 13

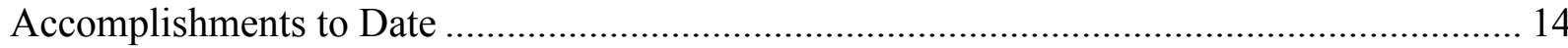

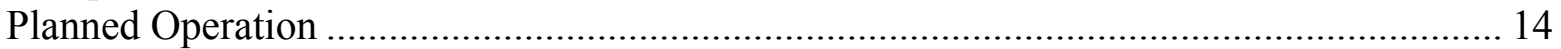

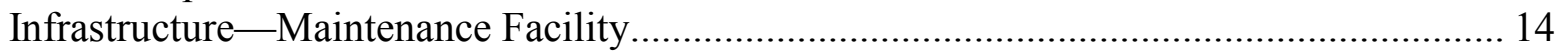

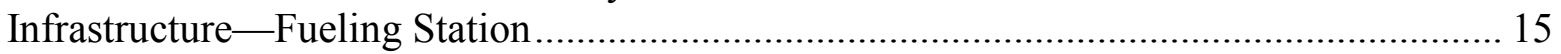

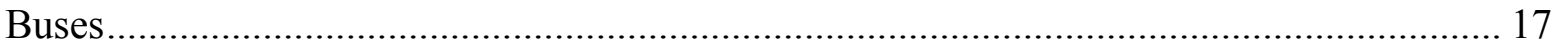

Total Miles and Fuel Cell System Hours.................................................................... 18

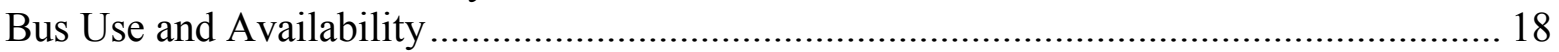

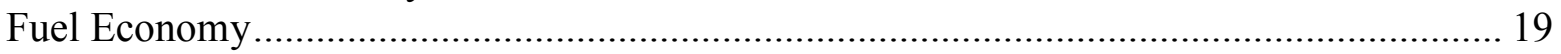

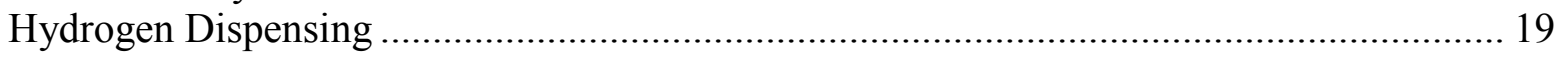

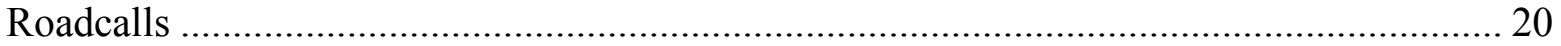

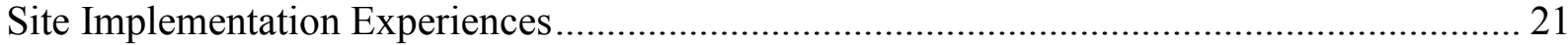

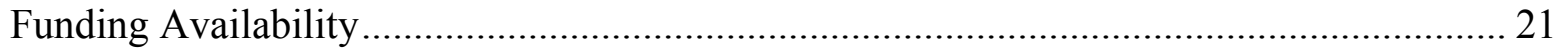

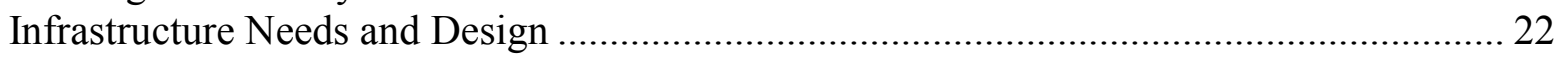

Vehicle Availability and Performance ……………............................................................ 23

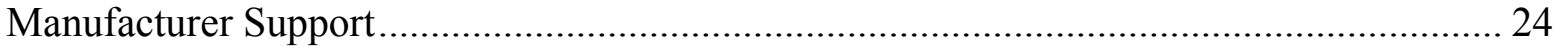

Emergency Response and Building Codes .................................................................... 25

Fuel Availability and Fueling Capability ........................................................................ 26

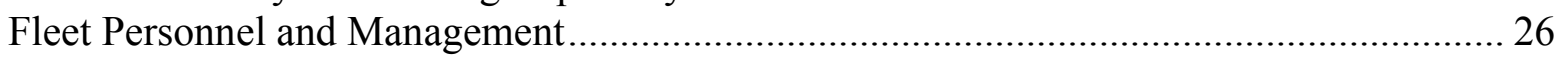

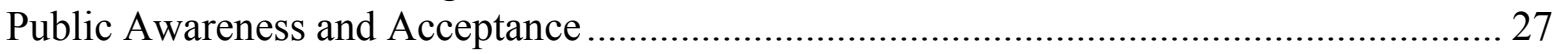

Data Collection, Analysis, and Reporting ………………………………………........... 28

Industry's Needs for Continued Successful Implementation......................................................... 29

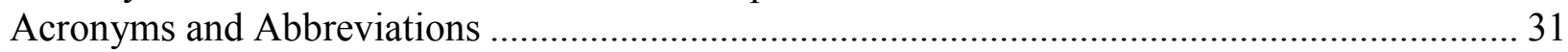




\section{Introduction and Background}

This report reviews past and present fuel cell bus technology development and implementation, specifically focusing on experiences and progress in the United States. This review encompasses results from the U.S. Department of Energy (DOE)/National Renewable Energy Laboratory (NREL) fuel cell bus evaluations as well as plans for the Federal Transit Administration's (FTA) National Fuel Cell Bus Program. Also provided is an exploration of policy drivers for the development of fuel cell propulsion in transit buses. The primary focus is on descriptive comparisons of fuel cell transit bus operation in the United States and on industry's need to continue successful implementations of these advanced technologies.

The late 1980s and early 1990s were a period of increased interest in reducing transit bus emissions and exploring alternatives to traditional diesel-powered transit buses. As a result, the first U.S. fuel cell bus (FCB) demonstration programs were implemented. These early efforts focused on proving the concept of fuel cells to power transit buses. Most notable was the Georgetown Fuel Cell Bus Program funded by the FTA, which demonstrated its first fuel cell bus in 1994, a 30-ft transit bus powered by a phosphoric acid fuel cell.

Much of what was done in the 1990s was proof-of-concept work to verify that fuel cell power systems could be packaged into a transit bus. Those early demonstrations identified areas of development needed to prepare fuel cell propulsion systems for heavy-duty vehicle service. Examples include the following:

- Reducing the size of the fuel cell stack

- Increasing the power density of the fuel cell stack

- Reducing the overall weight of the fuel cell and electric propulsion system

- Developing a hydrogen infrastructure for vehicle use

- Optimizing electric motors and control systems for heavy-duty vehicles

- Demonstrating that electric propulsion systems are safe for transit vehicles and perform well in environmental extremes (at high and low temperature and humidity).

Table 1 is an overview of many of the fuel cell transit bus development projects in the United States, Canada, Europe, and elsewhere around the world, from these early development activities to current demonstration efforts focused on bringing the technology toward commercialization. Figure 1 shows several of the fuel cell buses described in the table. 
Table 1. Overview of Worldwide Fuel Cell Transit Bus Demonstrations

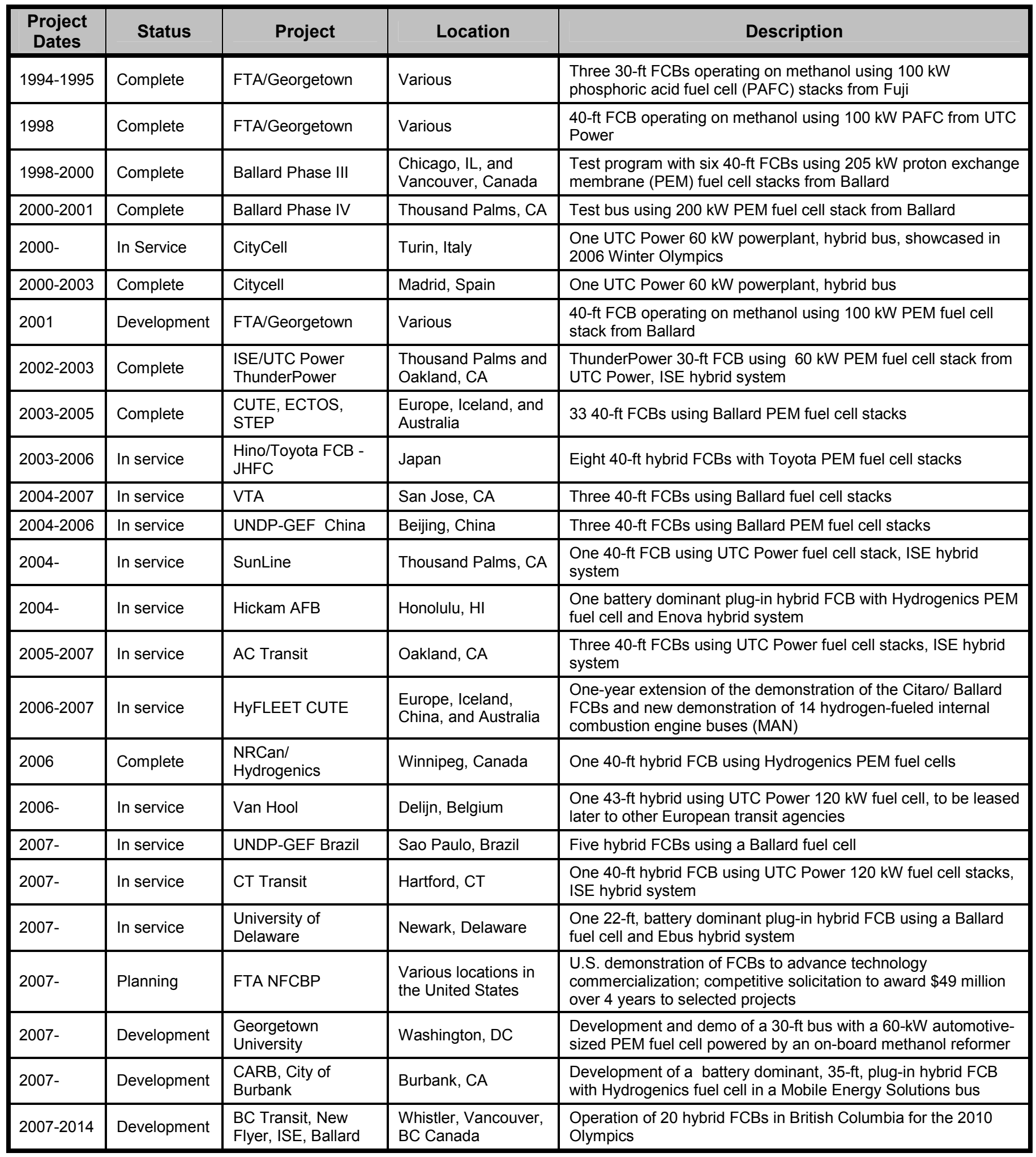




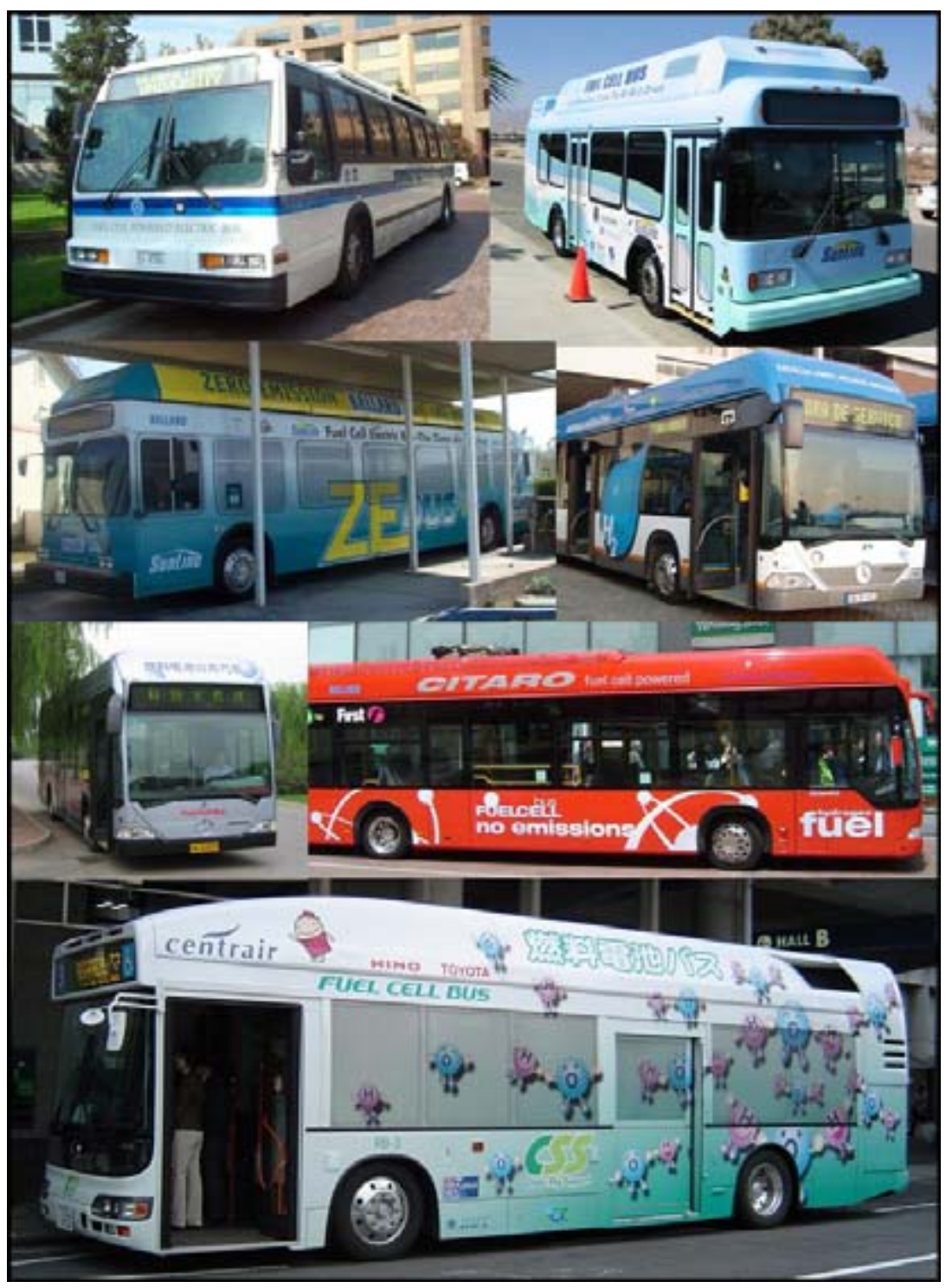

Figure 1. Photos from fuel cell bus demonstrations around the world

At the same time as these early fuel cell transit bus activities, transit agencies were participating in demonstrations to commercialize both compressed natural gas (CNG) and then diesel hybrid technologies for buses. These experiences supported the development of fuel cell transit buses by allowing participants to gain familiarity with the use of gaseous fuels in buses and the related infrastructure (and thus reducing the learning curve associated with hydrogen use) and electric hybrid propulsion (providing more familiarity with common components such as energy storage systems, motors, and computer controllers).

\section{U.S. Fuel Cell Bus Demonstrations and Evaluations}

Historically, the primary funding organizations for U.S. fuel cell and hydrogen-powered transit bus demonstrations has been DOE and the U.S. Department of Transportation (DOT) through the FTA. 


\section{DOE Fuel Cell and Hydrogen Powered Transit Bus Evaluations}

DOE has been involved in hydrogen fuel cell propulsion and infrastructure development for many years. As part of this development, DOE is evaluating hydrogen and fuel cell transit buses under the Technology Validation effort within the Hydrogen, Fuel Cells \& Infrastructure Technologies (HFCIT) Program. This DOE program integrates activities in hydrogen production, storage, and delivery with transportation and stationary fuel cell applications. Under Technology Validation, learning demonstrations are conducted to validate hydrogen and fuel cell technologies in real-world transportation applications in parallel with hydrogen infrastructure. The data collected and analyzed are used to verify performance targets and assess technology readiness.

NREL, a DOE national laboratory, works with manufacturers, fleets, fuel providers, and industry groups to evaluate hydrogen and fuel cell vehicles in both light-duty and heavy-duty applications. Since 2000, NREL has completed many evaluations of heavy-duty vehicles such as transit buses and heavy trucks. These include evaluations of hydrogen and fuel cell transit buses that were developed and demonstrated under FTA's fuel cell bus program (such as the Ballard Phase IV fuel cell bus at SunLine Transit Agency). Table 2 lists current evaluations of hydrogen and fuel cell powered heavy vehicles conducted under this task. Using an established protocol, NREL provides comprehensive, unbiased results on the performance, operation, and costs of the buses in comparison to those of conventional-technology buses used in the same type of services.

Table 2. DOE/NREL Heavy Vehicle Fuel Cell/Hydrogen Evaluations

\begin{tabular}{|c|c|c|c|}
\hline Fleet & Vehicle/Technology & Number & Evaluation Status \\
\hline \multirow{2}{*}{$\begin{array}{l}\text { U.S. Air Force/Hickam Air Force } \\
\text { Base (Honolulu, HI) }\end{array}$} & $\begin{array}{l}\text { Shuttle bus: Hydrogenics and Enova, } \\
\text { battery-dominant fuel cell hybrid }\end{array}$ & 1 & $\begin{array}{l}\text { Shuttle bus in operation; } \\
\text { data collection started }\end{array}$ \\
\hline & $\begin{array}{l}\text { Delivery van: Hydrogenics and Enova, } \\
\text { fuel cell hybrid }\end{array}$ & 1 & $\begin{array}{l}\text { Van in operation; data } \\
\text { collection started }\end{array}$ \\
\hline $\begin{array}{l}\text { Alameda-Contra Costa Transit } \\
\text { District (Oakland, CA) }\end{array}$ & $\begin{array}{l}\text { Van Hool/UTC Power fuel cell hybrid } \\
\text { transit bus integrated by ISE Corp. }\end{array}$ & 3 & $\begin{array}{l}\text { In process; preliminary } \\
\text { results reported Mar. } 2007\end{array}$ \\
\hline \multirow{2}{*}{$\begin{array}{l}\text { SunLine Transit Agency } \\
\text { (Thousand Palms, CA) }\end{array}$} & $\begin{array}{l}\text { New Flyer/ISE Corp. hydrogen } \\
\text { internal combustion engine transit bus }\end{array}$ & 1 & $\begin{array}{l}\text { In process; preliminary } \\
\text { results reported Feb. } 2007\end{array}$ \\
\hline & $\begin{array}{l}\text { Van Hool/UTC Power fuel cell hybrid } \\
\text { transit bus integrated by ISE Corp. }\end{array}$ & 1 & $\begin{array}{l}\text { In process, preliminary } \\
\text { results reported Feb. } 2007\end{array}$ \\
\hline $\begin{array}{l}\text { Connecticut Transit (Hartford, } \\
\text { CT) }\end{array}$ & $\begin{array}{l}\text { Van Hool/UTC Power fuel cell hybrid } \\
\text { transit bus integrated by ISE Corp. }\end{array}$ & 1 & $\begin{array}{l}\text { Bus in operation; data } \\
\text { collection started }\end{array}$ \\
\hline $\begin{array}{l}\text { Santa Clara Valley } \\
\text { Transportation Authority (VTA), } \\
\text { (San Jose, CA) and San Mateo } \\
\text { County Transit District } \\
\text { (SamTrans) (San Carlos, CA) }\end{array}$ & Gillig/Ballard fuel cell transit bus & 3 & $\begin{array}{l}\text { Complete and reported in } \\
2006\end{array}$ \\
\hline $\begin{array}{l}\text { SunLine Transit Agency } \\
\text { (Thousand Palms, CA) }\end{array}$ & $\begin{array}{l}\text { ISE Corp./ UTC Power ThunderPower } \\
\text { hybrid fuel cell transit bus }\end{array}$ & 1 & $\begin{array}{l}\text { Complete and reported in } \\
2003\end{array}$ \\
\hline
\end{tabular}

\section{FTA Fuel Cell and Hydrogen-Powered Transit Bus Projects}

The FTA is at the forefront of the research, development, and demonstration of fuel cell buses. The agency led early efforts to demonstrate fuel cell propulsion feasibility and proof-of-concept demonstrations in a liquid-fueled transit bus development program with Georgetown University. The FTA also led a demonstration of three hydrogen fuel cell buses at the Chicago Transit Authority and one of three different types of fuel cell buses at SunLine Transit Agency. Fuel cell technology holds the promise of greatly reduced emissions, quiet operation, and reduced fuel consumption for transit fleets. The early introduction of hydrogen fuel cell buses is expected to 
pave the way for later successful commercialization of fuel cells in other transportation applications.

The FTA is working with industry to coordinate diverse efforts in hydrogen and fuel cell buses to accelerate their commercial viability and to help accelerate the successful commercialization of hydrogen and fuel cell propulsion. Current efforts focus on dramatically improving the energy efficiency, emissions, performance, and cost-effectiveness of the 40-ft heavy-duty transit bus, the most prevalent vehicle used by U.S. transit agencies.

The agency's fuel cell bus development and demonstration efforts complement other hydrogen and fuel cell research efforts within DOT, including codes, standards and best practices development; safety research and validation; first responder education; and hydrogen transport technologies.

\section{National Fuel Cell Bus Program}

The FTA's newest development program is the National Fuel Cell Bus Program (NFCBP), which was established as part of the Safe, Accountable, Flexible, Efficient Transportation Equity Act: a Legacy for Users (SAFETEA-LU) transportation authorization. The program designates \$49 million in funding for 2006 through 2009 to facilitate the development of commercially viable fuel cell buses and technologies. The NFCBP's objectives include the following:

1. Develop and demonstrate fuel cell buses using innovative and improved fuel cell bus technologies.

2. Develop and demonstrate innovative and improved components and technologies for fuel cell buses, including fuel cell technologies, energy storage, transit bus systems integration, and power electronics technologies.

3. Advance different fuel cell technologies that may be viable for transit.

4. Develop an understanding of the requirements for market introduction. This includes fuel supply, fueling infrastructure, supplier networks, maintenance, safety, insurance, education, performance, support, etc.

5. Enhance the awareness of, and education about, fuel cell bus technologies.

6. Collaborate in the development of design standards for fuel cell bus technologies.

7. Compile and maintain information on the state of fuel cell bus technologies development and needs.

The NFCBP awards were announced in November 2006. The FTA competitively selected three nonprofit organizations - the Center for Transportation and the Environment (CTE), the Northeast Advanced Vehicle Consortium (NAVC), and Westart-CALSTART - to administer projects under the program. A balanced portfolio of projects was selected to best advance fuel cell bus commercialization. The FTA selected 14 separate projects in all (as shown in Table 3), including eight planned demonstration projects. These projects include both evolutionary and "clean sheet" approaches. They incorporate multiple drive technologies and configurations, fuel cell stacks in various sizes, and various energy storage technologies. Two component technology projects and four supporting and outreach projects were also selected. 
The FTA is collaborating with NREL to ensure that data are collected on all fuel cell bus demonstrations under the program. The evaluations will be coordinated with ongoing DOE evaluations. NREL will use the standard data collection and analysis protocol established for DOE heavy-duty vehicle evaluations. Results will be published at regular intervals and will help to accomplish the following:

- Measure the progress of fuel cell buses toward commercialization.

- Provide credible and consistent data collection and analysis for comparison.

- Enable the federal government to understand the status and progress of the work and to continue funding necessary research and development.

- Ensure that FTA funds are used to push the technology forward.

- Provide information to the transit industry that will aid those making purchasing decisions on the technology.

\section{Other Fuel Cell and Hydrogen Transit Bus Projects}

The FTA also supports several other ongoing fuel cell and hydrogen transit bus projects, including the following:

- SunLine HHICE - a hybrid hydrogen internal combustion engine (HHICE) bus in service in the Palm Springs area of California. This New Flyer 40-ft bus has a hybrid system by ISE and uses a Ford ICE engine modified to operate on hydrogen and ultracaps for energy storage (participating in the NREL evaluation).

- SunLine ThunderPower bus - an existing 30-ft El Dorado fuel cell bus, which is now being upgraded with the latest ISE hybrid system and a new $75 \mathrm{~kW}$ Ballard HD6 fuel cell module (planned participation in the NREL evaluation).

- Delaware - a 22-ft Ebus fuel cell bus has a battery-dominant hybrid system with nickel cadmium batteries and a $20 \mathrm{~kW}$ Ballard fuel cell. The bus will be operated in a campus loop shuttle during the school year and by the local transit agency when the university is not in session.

- CT Transit - a 40-ft Van Hool fuel cell bus with an ISE hybrid system and a fuel cell by UTC Power. This bus is the fifth bus from the AC Transit procurement. The bus is in operation on a free shuttle route around the downtown area of Hartford, Connecticut. The agency also plans to test the bus on other routes around the area (participating in the NREL evaluation).

- New Haven, Connecticut - the agency is planning to demonstrate two hydrogenpowered buses, and one will include a fuel cell system. 
Table 3. Summary of FTA NFCBP Projects

Demonstration Projects

Dual Variable Output Fuel Cell Hybrid Bus Validation and Testing-Develop battery-dominant 35-ft plug-in hybrid fuel cell bus (Hydrogenics) and demonstrate in Columbia, SC, Birmingham, AL, and cities in CT (CTE)

UTC Power Fuel Cell Bus Demonstration-Advanced bus development and in-service evaluation of hybrid 40-ft fuel cell buses; enhanced UTC Power 120 kW PEM fuel cell with upgraded seals, catalysts, bipolar plates, balance of plant (NAVC)

GE Lightweight Fuel Cell Hybrid Bus-Advanced propulsion system integrated with a lightweight bus platform for field evaluation focused on advanced battery technologies for lower cost (GE Global Research, A123Systems) (NAVC)

Massachusetts Hydrogen Fuel Cell Powered Bus Fleet-Advanced bus development and in-service demonstration; integrate Nuvera $82 \mathrm{~kW}$ fuel cell with drive system from ISE Corp. and advanced energy storage; demonstration effort includes Nuvera's novel PowerTap fueling infrastructure (NAVC)

Ballard Fuel Cell Bus Program-Develop and demonstrate two 40-ft buses for operation in upstate New York for up to 2 years; Next-generation Ballard HD6 fuel cell module (150 kW) in hybrid configuration with ISE drive and ultracapacitors or batteries (NAVC)

American Advanced Fuel Cell Bus Program-Design and demonstrate 40-ft fuel cell bus with design improvements; in-service evaluation in hot desert climate (SunLine Transit Agency, New Flyer, ISE Corp, UTC Power) (WestStart-CALSTART)

Compound Fuel Cell Hybrid Bus for 2010_Develop 40-ft fuel cell bus with fuel cell auxiliary power unit coupled with diesel engine; demonstrate for one year at San Francisco Muni; small Hydrogenics PEM fue cell (12 kW twin or $16 \mathrm{~kW})$, BAE Systems drive, electrically driven accessories, advanced energy storage (WestStart-CALSTART)

AC Transit HyRoad: Commercialization of Fuel Cells for Public Transit-Accelerated testing to failure (partial phase 1) of existing fuel cell buses (WestStart-CALSTART)

\section{Component Projects}

Hybrid Fuel Cell Power Converter-Design and bench-test bidirectional, DC-DC converter for reduced cost, weight, and volume (US Hybrid, ISE Corp., Hydrogenics) (WestStart-CALSTART)

Integrated Auxiliary Module for Fuel Cell Buses-Design, fabricate, and bench test Integrated

Auxiliary Module (US Hybrid) (WestStart-CALSTART)

\section{Supporting Projects}

Survey and Analysis of Bus Demonstrations-Document and analyze bus demonstrations around the world from 2002-2007 (Breakthrough Technologies Inst., PE Europe, Western Australia Dept. of Planning and Infrastructure) (CTE)

FTA National Fuel Cell Bus Working Group-Support for FTA U.S. Fuel Cell Bus Working Groups and data collection efforts; two projects (NAVC)

International Fuel Cell Bus Working Group and Workshops-Coordinate activities for International

Fuel Cell Working Group and collaboration and outreach efforts for international fuel cell bus

demonstration efforts (NAVC) 


\section{Why Develop Fuel Cell and Hydrogen Technology for Transit Buses?}

Over the past several years, many nations around the world have increasingly focused on developing new ways to provide clean energy. In the United States, government and industry partners are exploring a variety of technologies to meet the growing energy needs of the population in more efficient and renewable ways. Technologies being pursued in this country include using hydrogen and fuel cells in transportation applications.

Although transit vehicles make up less than $2 \%$ of the total number of vehicles in the nation, this application is one of the first ones demonstrating fuel cell propulsion systems. Transit buses have several characteristics that make them particularly well suited for demonstrating fuel cell usage in transportation. They are ideal applications for advanced technologies such as fuel cell propulsion because they

- Are centrally located and fueled.

- Are government subsidized.

- Are professionally operated and maintained.

- Operate on a fixed route and fixed schedule.

- Have greater tolerance for the added weight and volume requirements of advanced systems.

- Have less rigorous start-up and pull-out requirements.

- Provide greater exposure to the positive benefits of advanced technologies, which leads to broader public knowledge and acceptance.

To date, 20 fuel cell buses have been demonstrated in the United States; ten of them are currently in service. As many as 15 more fuel cell buses are in the planning and development stages for demonstration over the next 4 years. As momentum for these projects increases, there is a need to document what has been accomplished and learned so far in terms of fleet deployment experiences (in addition to technical results) and what significant challenges remain to fully commercialize and deploy the technology. The operational and maintenance experiences obtained by introducing fuel cell vehicle technologies in buses should significantly enhance successful introductions of fuel cells in other applications. 


\section{Regulation and Policy Drivers for Fuel Cell Buses}

In general, air quality is reported as the primary driver for developing fuel cell propulsion in transit buses. Most transit buses are operated in densely populated urban areas in which the traffic congestion results in high levels of pollution. Reducing the use of petroleum has also become an important driver, especially in light of recent price increases and the expectation that they will remain high. As a result, many transit agencies are facing increasing pressure from environmental groups, the public, and economic conditions to use the cleanest and most advanced technology available. On the federal side, the FTA is providing funds to research advanced technologies that can eventually be adopted by fleets. On the state level, California has enacted various rules to lower pollution from several transportation sectors, including transit buses.

\section{Federal Transit Administration}

The FTA's research efforts focus on innovations that can improve personal mobility, minimize fuel consumption and air pollution, and increase transit ridership. To that end, FTA focuses much of its advanced vehicle research efforts on propulsion technologies that can provide energy and emissions benefits when compared with conventional buses. Of particular interest is fuel cell technology because of the potential for buses to operate in a clean, quiet, efficient manner on hydrogen fuel, thereby reducing U.S. dependence on imported oil.

Transit has long been at the forefront of the research, development, and demonstration of alternatives to traditional diesel-powered transit buses. The FTA supported the early development of CNG and hybrid powered buses, both of which have proved to be successful commercial options for transit fleets. Advances in both gaseous fuels and electric drive technologies have provided valuable advances in fuel cell bus commercialization.

Through the NFCBP, the FTA has set rigorous performance objectives for advancing fuel cell bus technologies by 2012. These performance objectives will be reexamined periodically through FTA's strategic planning process to ensure that the technical targets are rigorous yet realistic. The NFCBP's performance objectives are as follows:

- Achieve a fuel cell bus vehicle cost of no greater than five times that of a commercial transit bus.

- Achieve a 4 to 6 years or 20,000 to 30,000 hours of durability for the fuel cell propulsion system.

- Achieve double the fuel efficiency of a commercial transit bus, to enhance energy security.

- Achieve fuel cell bus performance equal to, or better than, that of an equivalent commercial transit bus in terms of acceleration, gradability, range, braking distance, etc.

- Exceed the 2010 heavy-duty bus emissions standards.

- Foster economic competitiveness in fuel cell bus technologies.

- Increase public acceptance for fuel cell bus technologies. 


\section{California Zero-Emission Bus Rule}

The state of California is leading the nation in deployment of low- and zero-emission propulsion technologies. Nowhere else in the country are transit agencies under more pressure to reduce fleet emissions. In 2000, the California Air Resources Board (CARB) established a new transit bus fleet rule which set more stringent emission standards for new urban bus engines and promoted advances in the cleanest technologies — specifically, zero-emission buses (ZEBs).

The fleet rule required transit agencies to choose a compliance path - alternative fuel or dieselfor meeting emission standards. This selection determined the fuel type for new bus acquisitions through model year 2015. The alternative fuel path could include low-emission alternative fuels such as compressed or liquefied natural gas, propane, electricity, hydrogen, or another advanced technology (such as gasoline hybrid-electric). Agencies choosing the diesel path were required to reduce fleet average emissions through methods such as purchasing the cleanest diesel engines and retrofitting existing diesel engines with emission control devices (i.e., diesel particulate filters).

All transit agencies with 200 or more buses were required to eventually procure ZEBs as $15 \%$ of all new bus purchases. Agencies choosing the diesel path were scheduled to meet these requirements on a more accelerated timeline than those on the alternative fuel path. Diesel path fleets were also required to demonstrate the use of ZEB technology in revenue service starting in 2006. ZEB technologies that qualify for this regulation include electric propulsion (battery or trolley buses) and fuel cell propulsion.

At the time of the original ruling, 11 agencies in the state had more than 200 buses. Of those agencies, five had selected the diesel path and were subject to the required ZEB demonstration. Because the San Francisco Municipal Railway (Muni) operates electric trolley buses, it already meets the ZEB rule. The remaining four agencies developed programs for demonstrating fuel cell buses, the first of which began revenue service in February 2005. One agency planned an additional (voluntary) demonstration of a fuel cell bus, which was not subject to the ZEB rule. Table 4 lists the California agencies participating in current ZEB demonstration projects.

Table 4. California Transit Agencies Participating in ZEB Demonstrations

\begin{tabular}{|l|c|c|}
\hline \multicolumn{1}{|c|}{ Transit Agency } & Location & Required? \\
\hline Alameda-Contra Costa Transit (AC Transit) & Oakland & Yes \\
\hline Golden Gate Transit (GGT) & San Rafael & Yes \\
\hline San Mateo County Transit District (SamTrans) & San Mateo & Yes \\
\hline Santa Clara VTA & San Jose & Yes \\
\hline SunLine Transit Agency & Thousand Palms & No \\
\hline
\end{tabular}

Each agency participating in a demonstration is required to report the results to CARB. Staff use the results to help determine the status of the technology, which would be reported to the Board along with recommendations for necessary modifications to the rule.

The CARB fleet rules have been modified twice since the original ruling went into effect, mainly to change the effective dates of fuel cell bus demonstrations and future bus procurements. After reviewing data from early demonstrations in late 2006, the Board determined that, despite the efforts of transit agencies and manufacturers, the technology had not progressed as quickly as 
originally expected. The modifications to the rule also included an advanced demonstration program of ZEBs and a delay of the 15\% purchase requirement to January 1, 2011 (diesel path), and January 1, 2012 (alternative fuel path).

Affected agencies on the diesel path are required to participate in an advanced ZEB demonstration, with buses being placed into revenue service beginning January 1, 2009. This demonstration will help continue the momentum of technology development and allow transit agency staff to gain more experience with the buses. Agencies have the option to participate as a single agency or in a multiple-agency demonstration. For the single-agency option, at least six ZEBs must be procured and in service. The multiple-agency option requires a minimum of 12 total ZEBs, and at least three per site. Participating agencies must report results to CARB at regularly defined intervals. CARB staff will use these results to determine progress toward commercialization and to recommend modifications to the ruling, as necessary, no later than July 2009. For more information on the ruling, see www.arb.ca.gov/msprog/bus/zeb/zeb.htm.

\section{Other Factors That Could Impact U.S. Commercialization}

Other factors have the potential to affect the success and timing of full commercialization of fuel cell buses in the United States. These include the adoption of California emission regulations by other states and the progress made in major fuel cell bus commercialization projects outside the United States.

Several states have adopted, or plan to adopt, the emission regulations set by the State of California. Some of those states have included zero-emission vehicle mandates as part of their regulations. Although these regulations specifically target light- and medium-duty vehicles, they can still help build public awareness of the need to reduce overall emissions. This could lead to added interest and funding for ZEB technology in those states.

In addition, many other countries are also developing and demonstrating fuel cell bus technology. Of particular interest is a project in British Columbia, Canada. That project calls for a fleet of 20 full-size transit buses to be produced in time for the 2010 Winter Olympic Games in Whistler. Afterward, the buses are required to continue to operate in regular service in the BC Transit fleet. The success of this and other projects around the world could have a positive impact on the development of commercial fuel cell buses in the United States. 


\section{Development Path for New Transit Bus Technologies}

Typically, new vehicle propulsion technologies for transit buses are developed and introduced in six phases:

1. Concept development - the process of determining concepts, market needs and strategy, and technology requirements

2. Technology research and development - research into the specific needs of the propulsion and vehicle powertrain as well as integration needs

3. Vehicle development, design, and integration - actual test vehicle integration and laboratory testing

4. Manufacturing and assembly integration - study of component suppliers and needs for manufacturing a small number of vehicles

5. Vehicle demonstration, testing, and preproduction - a phase typically executed in three steps:

a. Field testing and design shakedown (one to two vehicles)

b. Full-scale demonstration and reliability testing (five to 10 vehicles at several locations)

c. Limited production (50 to 100 vehicles at a small number of locations)

6. Deployment, marketing, and support - the first fully commercially available products

The time for each phase can vary greatly and depend on many factors, including the continued availability of funding and appropriate selection of a demonstration site. The fuel cell buses in U.S. demonstrations are considered prototypes in phase 5 of this process. In the three-step process that usually makes up phase 5, U.S. fuel cell bus demonstrations are now somewhere between the first and second step. The next major step in this process will be to produce 50 to 100 more fuel cell buses for further demonstrations.

For perspective, the diesel propulsion transit bus is the baseline technology, and the CNG propulsion transit bus moved beyond the deployment phase several years ago. The diesel hybrid propulsion transit bus entered the deployment phase in the last several years when large purchases were made for New York City Transit, King County Metro (Seattle), Toronto, and San Francisco transit systems; however, this does not mean that the diesel hybrid propulsion system is fully optimized for transit service. 


\section{Documented Fuel Cell Transit Bus Experience}

As discussed earlier, in-service demonstrations of fuel cell buses are essential for commercializing the technology. Controlled testing in a laboratory or on a test track cannot fully reveal the kinds of problems that might occur in the field. Therefore, the technology needs to be placed in the hands of users and tested in service. Manufacturers use in-service demonstrations to evaluate how the systems and components perform and verify the results from lab testing and modeling. For these demonstrations, the transit agency becomes an active partner in the development process. The agency needs to understand this role and be prepared to aid the manufacturer as they further optimize and improve the systems. During the process, downtime for the test buses is expected, as manufacturers identify potential performance issues and continue to improve specific components as well as the overall system. These projects are critical for measuring progress and determining the next steps toward commercialization.

This section summarizes overall accomplishments and explores implementation and operational experiences at three DOE/NREL evaluation sites, at which FTA had funded development and demonstration work under the FTA fuel cell research and demonstration program. NREL evaluated in-service experiences at these sites:

- Santa Clara Valley Transportation Authority (VTA) in San Jose, California, along with partner transit agency San Mateo County Transit District (SamTrans) in San Carlos, California ${ }^{1}$

- SunLine Transit Agency in Thousand Palms, California (in the Palm Springs area) ${ }^{2}$

- Alameda-Contra Costa Transit District (AC Transit) in Oakland, California, along with its partner transit agency, Golden Gate Transit (GGT) in San Rafael,

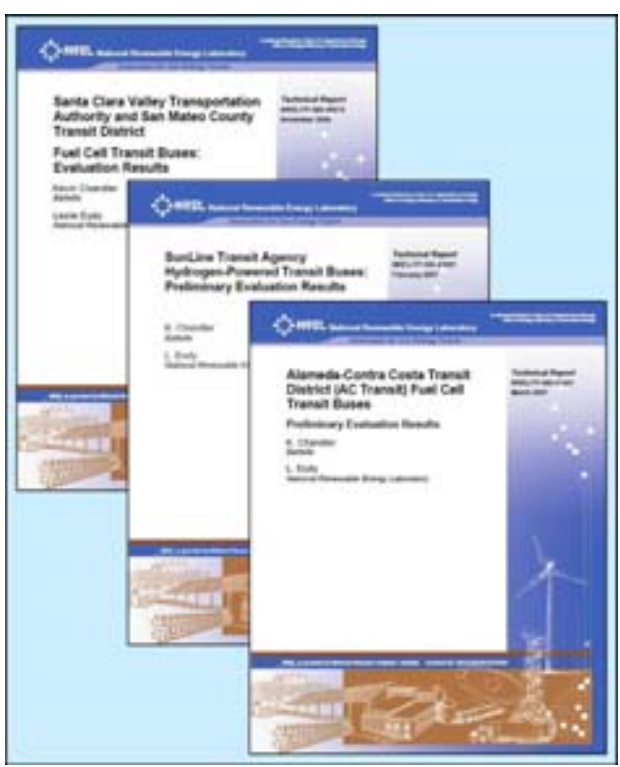
California $^{3}$

Although these are not the only fuel cell bus demonstrations being conducted in the United States, these fleets were selected for this discussion because detailed results are available. The published results ${ }^{4}$ of these three evaluation sites are used in this report to compare experiences in demonstrating current fuel cell transit bus technologies in the United States.

\footnotetext{
${ }^{1}$ Santa Clara Valley Transportation Authority and San Mateo County Transit District, Fuel Cell Transit Buses: Evaluation Results, November 2006, NREL/TP-560-40615.

${ }^{2}$ SunLine Transit Agency Hydrogen-Powered Transit Buses: Preliminary Evaluation Results, February 2007, NREL/TP-560-41001.

${ }^{3}$ Alameda-Contra Costa Transit District (AC Transit), Fuel Cell Transit Buses: Preliminary Evaluation Results, February 2007, NREL/TP-560-41041.

${ }^{4}$ Hydrogen-powered transit bus evaluations from NREL are available at the following Web site:

http://www.nrel.gov/hydrogen/proj_fc_bus_eval.html
} 


\section{Accomplishments to Date}

This section summarizes accomplishments to date for the three evaluation sites: VTA, SunLine, and AC Transit.

\section{Planned Operation}

Each of the three sites had similar plans for operating their fuel cell buses. Table 5 shows each site's buses, planned service, and current status. Both SunLine and AC Transit intend to operate their fuel cell buses at a higher usage rate (up to 16 hours per day, 5-days a week) than the 8hour usage shown in the table; however, this is not planned to start until at least July 2007.

Table 5. Planned Demonstration Operation

\begin{tabular}{|l|c|l|l|l|}
\hline \multicolumn{1}{|c|}{ Site } & Buses & \multicolumn{1}{c|}{ Planned Service } & \multicolumn{1}{c|}{ Demonstration Period } & \multicolumn{1}{c|}{ Current Status } \\
\hline VTA & 3 & $\begin{array}{l}\text { Added revenue service; } \\
\text { 8-hour blocks, } \\
\text { weekdays only }\end{array}$ & $\begin{array}{l}\text { 24 months, } \\
\text { August 2004-July 2006; } \\
\text { started February 28, 2005 }\end{array}$ & $\begin{array}{l}\text { Still operating } \\
\text { beyond the } \\
\text { warranty period }\end{array}$ \\
\hline SunLine & 1 & $\begin{array}{l}\text { Revenue service; } \\
\text { generally 8-hour blocks, } \\
\text { 5 days per week }\end{array}$ & $\begin{array}{l}\text { 24 months, } \\
\text { January 2006-December 2007; } \\
\text { started December 21, 2005 }\end{array}$ & In demonstration \\
\hline AC Transit & 3 & $\begin{array}{l}\text { Revenue service; } \\
\text { 8-hour blocks, } \\
\text { weekdays only }\end{array}$ & $\begin{array}{l}\text { 24 months, } \\
\text { April 2006-March 2008; } \\
\text { started March 20, 2006 }\end{array}$ & In demonstration \\
\hline
\end{tabular}

Infrastructure-Maintenance Facility

The maintenance facility for each site is shown in Figure 2. The facility was either newly constructed or upgraded as required for the demonstration of the fuel cell buses.

- VTA - The maintenance facility was newly constructed on site at the Cerone Division in San Jose, California. This facility was completed in June 2005 but was not cleared for use until November 2005. It is a free-standing building with the equivalent of two maintenance bays and includes working space and parts inventory for the fuel cell buses. The building is equipped with Class I, Division 2 electrical fixtures, a hot water heating system, hydrogen and flame sensors (and alarms), a high-throughput ventilation system, and an antistatic coating on doors. The total cost was $\$ 4.4$ million for the facility, the fueling station, and the bus wash.

- SunLine-The maintenance facility was newly constructed on site at the Thousand Palms facility in 2000. This facility is located immediately behind the existing maintenance building; it is essentially a tent that can accommodate one to two buses and that was designed to vent hydrogen through the roof. All lighting within the tent structure and adjacent maintenance bay is rated Class I, Division 1 and is equipped with sensors that sound an alarm if a hydrogen leak is detected. The construction cost of this structure was approximately $\$ 50,000$.

- AC Transit-The maintenance facility was a modification of an existing maintenance bay (including space for two buses) at the East Oakland facility. The selected maintenance bay was isolated from the rest of the facility by a firewall. Safety features included sensors; ignition-free heating; antistatic, nonskid, grounded floor covering; high-speed roll-up doors; Class I, Division 2 lighting and electrical; and a higher capacity ventilation system. This modified maintenance bay does not allow a fuel cell bus in 
unless it is defueled to 600 psi onboard. The cost of the modifications required was about $\$ 1.5$ million, and the facility was cleared for operation in January 2006.

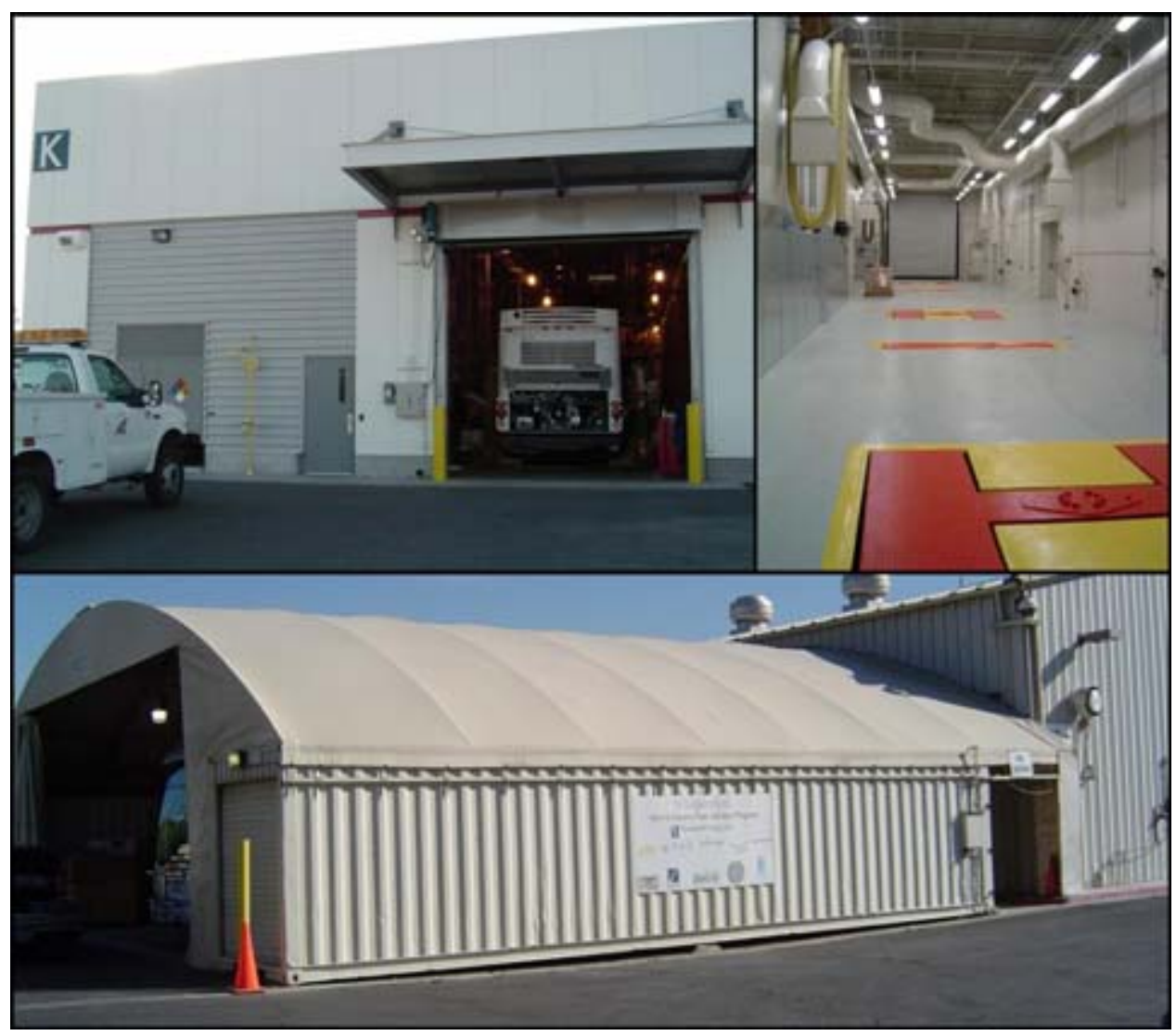

Figure 2. Hydrogen maintenance facilities at VTA (top left), AC Transit (top right), and SunLine (bottom)

\section{Infrastructure_Fueling Station}

The fueling facility for each site is shown in Figure 3. Each was newly constructed as required for the demonstration of the fuel cell buses.

- VTA - The fueling station features a 9,000 gallon cryogenic tank that stores liquid hydrogen, and gaseous hydrogen is available for dispensing into a bus at up to 6,000 psi (for a settled pressure on the bus of no more than 5,000 psi). This station was designed to have two compressors, and it employs a cascade buffer strategy to support fast fueling of each bus. The station is also equipped with sensors, alarms, and a monitoring system. The dispenser is equipped with a communications connection for monitoring tank pressure and temperature during fueling as well as a ground cable for safety. This fueling station was designed and installed by Air Products for approximately $\$ 480,000$ up front and approximately $\$ 4,400$ per month for lease payments. Air Products retains ownership of the VTA equipment and is required to maintain it. These costs do not include the price of the liquefied hydrogen delivered to the station by truck from Sacramento. 
- SunLine - Hydrogen is generated by an on-site, commercially available HyRadix Adéo natural gas reformer, which started operation in August 2006 (a prototype unit was in operation for more than a year before that). This unit cost $\$ 750,000$ for purchase and installation, as well as a $\$ 300,000$ contract for six years of maintenance. Hydrogen storage on site includes approximately $180 \mathrm{~kg}$, and dispensing is provided up to 5,000 psi onboard the bus.

- AC Transit-Hydrogen is generated by an on-site natural gas reformer from Chevron Technology Ventures. The station was operational in December 2005 and inaugurated for official service on March 13, 2006. The station has $366 \mathrm{~kg}$ of hydrogen storage at 6,250 psi. Two dispensers provide hydrogen to buses and several light-duty vehicles. Chevron provides all maintenance for the station. No costs for the entire fueling station have been released.

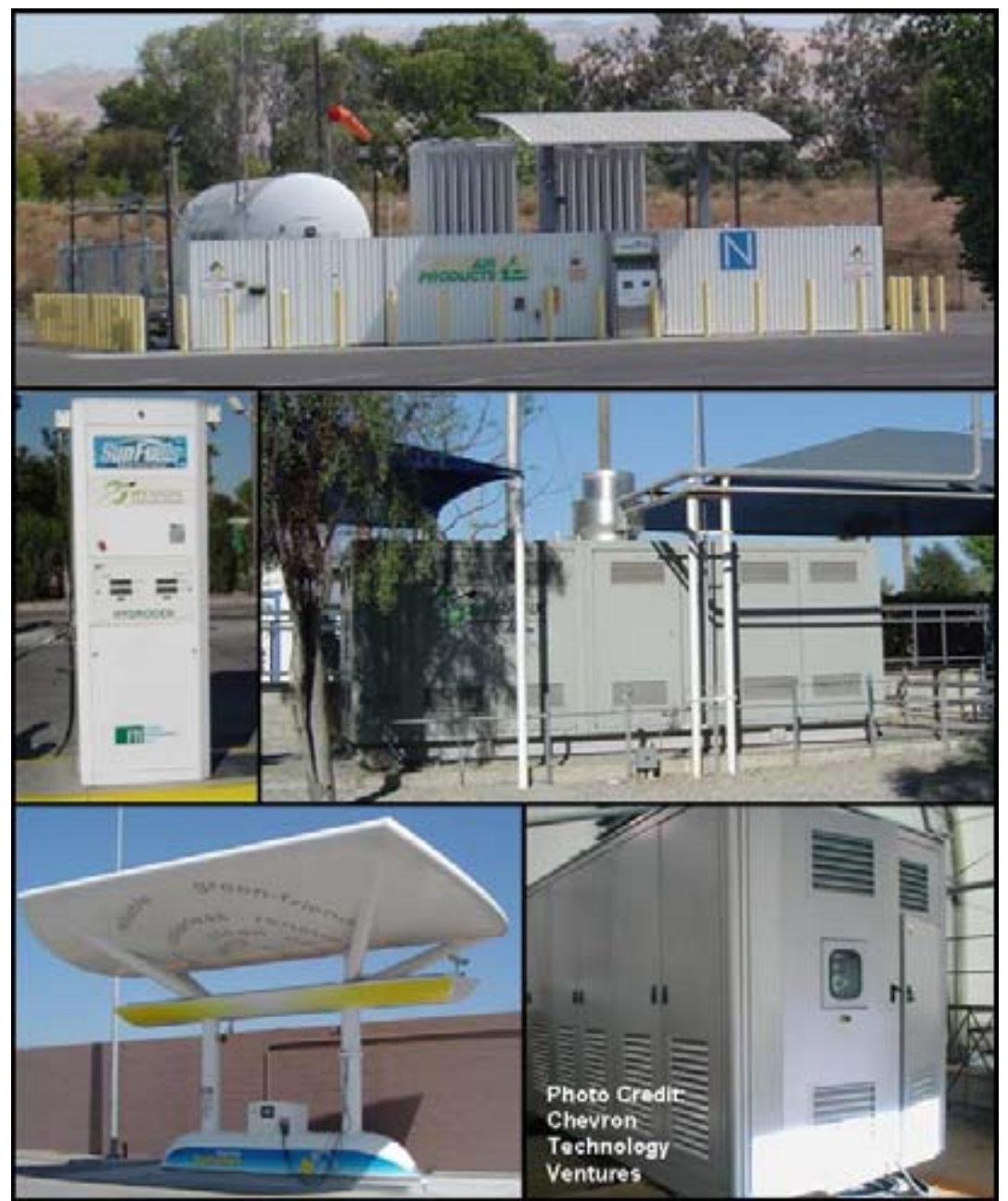

Figure 3. Hydrogen fueling stations at VTA (top), SunLine (middle), and AC Transit (bottom)

\section{Infrastructure-Other}

At VTA, there was also a need to upgrade or replace the existing bus wash. The buses are taller than a typical diesel or CNG bus, and there were some concerns with hydrogen leaking in the bus wash. The new bus wash is shown in Figure 4. 


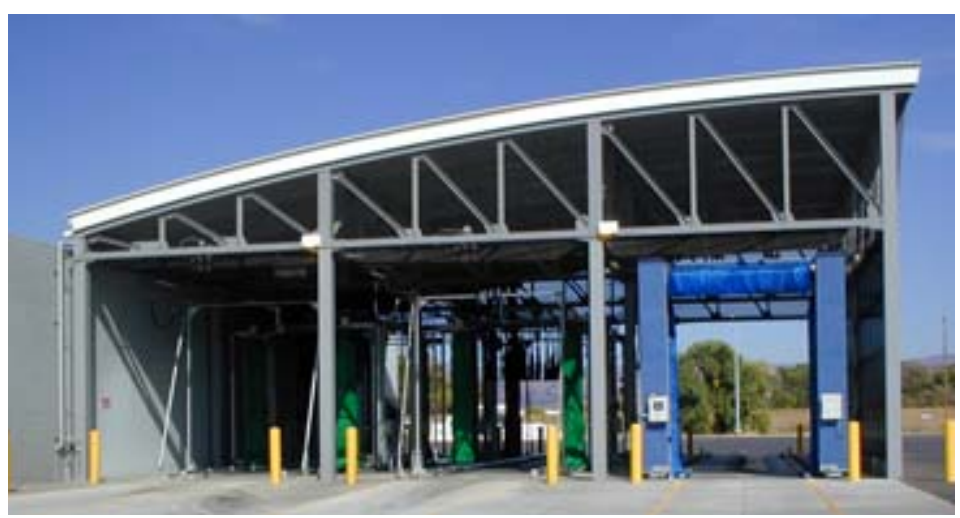

Figure 4. New bus wash facility at VTA

\section{Buses}

Figure 5 shows the three sites' fuel cell buses and several bus systems are described in Table 6 . VTA's fuel cell buses are low-floor Gillig buses with Ballard fuel cell systems, and the SunLine and AC Transit fuel cell buses are of the same design and are from Van Hool and ISE

Corporation with UTC Power fuel cells. The most important difference between the two designs is that the Van Hool/UTC Power bus incorporates a hybrid propulsion system with batteries for energy storage. The energy storage allows for regenerative braking, which has a significant impact on fuel economy. The purchase price of these buses is extremely high compared with that of a typical baseline transit bus. These fuel cell bus purchase prices include significant warranty coverage from the manufacturers including on-site staff from the fuel cell manufacturer and integrator, in the case of ISE Corp.

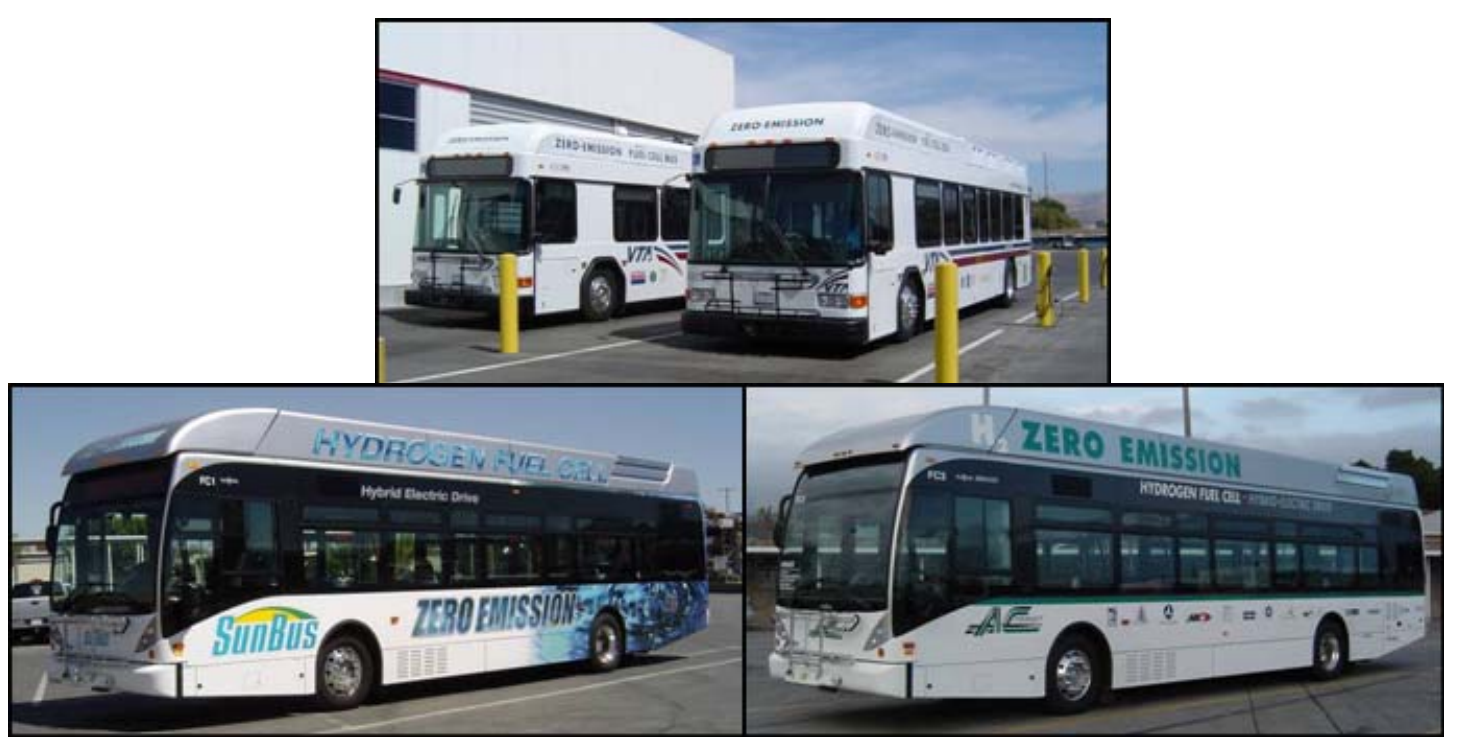

Figure 5. Fuel cell buses at VTA (top), SunLine (bottom left), and AC Transit (bottom right) 
Table 6. Fuel Cell Bus System Descriptions

\begin{tabular}{|c|c|c|}
\hline \multirow{2}{*}{ Vehicle System } & \multicolumn{2}{|r|}{ Fuel Cell Buses } \\
\hline & VTA & AC Transit \\
\hline Number of buses & 3 & 3 \\
\hline $\begin{array}{l}\text { Bus manufacturer and } \\
\text { model }\end{array}$ & Gillig low floor & Van Hool A330 low floor (ISE integration) \\
\hline Model year & 2004 & 2005 \\
\hline Length/width/height & $40 \mathrm{ft} / 102 \mathrm{in} / 144 \mathrm{in}$ & $40 \mathrm{ft} / 102 \mathrm{in} / 139 \mathrm{in}$ \\
\hline GVWR/curb weight & $40,600 \mathrm{lb} / 34,100 \mathrm{lb}$ & $43,240 \mathrm{lb} / 36,000 \mathrm{lb}$ \\
\hline Wheelbase & 284 in & 228 in \\
\hline Passenger capacity & $\begin{array}{c}37 \text { seated or } 29 \text { seated and } \\
\text { two wheelchairs; } \\
5 \text { standing }\end{array}$ & $\begin{array}{l}30 \text { seated or } 26 \text { seated and two wheelchairs; } \\
15 \text { standing }\end{array}$ \\
\hline $\begin{array}{l}\text { Engine manufacturer } \\
\text { and model }\end{array}$ & $\begin{array}{l}\text { Two Ballard fuel cell } \\
\text { modules P5-2 }\end{array}$ & $\begin{array}{c}\text { UTC Power } \\
\text { PureMotion }^{\top M} 120 \text { Fuel Cell Power System }\end{array}$ \\
\hline Rated power & $150 \mathrm{~kW}$ each (300 kW total) & $\begin{array}{l}\text { Fuel cell power system: } 120 \mathrm{~kW} \\
\text { Two electric drive motors: } 170 \mathrm{~kW} \text { total } \\
\text { (continuous) }\end{array}$ \\
\hline Accessories & Mechanical & Electrical \\
\hline Emissions equipment & None & None \\
\hline Transmission/retarder & $\begin{array}{c}\text { ZF transmission/integrated } \\
\text { retarder }\end{array}$ & $\begin{array}{l}\text { Gearbox/Flenders } \\
\text { regenerative braking }\end{array}$ \\
\hline Hybrid type & $\mathrm{N} / \mathrm{A}$ & Series, charge sustaining \\
\hline Energy storage & None & $\begin{array}{c}\text { Battery - } 3 \text { modules } / 216 \text { cells, sodium/nickel } \\
\text { chloride ZEBRA®; } 53 \mathrm{kWh} \text { capacity }\end{array}$ \\
\hline Fuel capacity & $55 \mathrm{~kg}$ hydrogen & $50 \mathrm{~kg}$ hydrogen \\
\hline $\begin{array}{l}\text { Bus purchase cost } \\
\text { (per bus) }\end{array}$ & $\$ 3.5$ million & \$3.1 million \\
\hline
\end{tabular}

\section{Total Miles and Fuel Cell System Hours}

Table 7 shows the total miles and fuel cell system hours for each of the three sites through June 2007. VTA's buses have been in operation the longest at 32 months. From the data, the overall average speed of operation for the three locations is as follows:

- VTA: $11.4 \mathrm{mph}$

- SunLine: $13.1 \mathrm{mph}$

- AC Transit: $11.3 \mathrm{mph}$

Table 7. Summary of Total Miles and Fuel Cell System Hours

\begin{tabular}{|l|c|l|c|c|c|}
\hline \multicolumn{1}{|c|}{ Site } & Buses & \multicolumn{1}{|c|}{ Period } & Months & $\begin{array}{c}\text { Total } \\
\text { Miles }\end{array}$ & $\begin{array}{c}\text { Total FC } \\
\text { System Hours }\end{array}$ \\
\hline VTA & 3 & November 2004-June 2007 & 32 & 65,627 & 5,741 \\
\hline SunLine & 1 & January 2006-June 2007 & 18 & 37,005 & 2,822 \\
\hline AC Transit & 3 & April 2006-June 2007 & 15 & 47,805 & 4,221 \\
\hline
\end{tabular}

\section{Bus Use and Availability}

Bus use and availability are indicators of reliability. The lack of bus usage may be an indication of downtime for maintenance or a purposeful reduction in work planned for the buses. 
Availability is presented as a measure by the percent of planned operating days in which one or more of the buses were actually available for passenger service. Table 8 shows fuel cell bus usage and availability for each of the three sites for only the evaluation period from the latest DOE/NREL evaluation report. The VTA fuel cell buses had the lowest average monthly miles; SunLine had the highest. The fuel cell buses' availability for operation was about the same for VTA and SunLine and significantly higher for AC Transit. For context, a typical baseline transit diesel or CNG bus would show 4,000 to 5,000 monthly miles and an availability of at least $85 \%$.

The primary reason that transit agencies have limited fuel cell bus operation is to ensure that, in case of a problem or on-road failure, the buses are operating during times when fully trained fuel cell bus mechanics are available. Agencies with several buses have also opted to keep one bus as a spare. This allows time for maintenance, training, and special events that can include one of the fuel cell buses. As a result, the fuel cell buses have not been accumulating as many miles per month as the conventional buses in the fleet.

Table 8. Bus Usage and Availability for the Evaluation Period

\begin{tabular}{|l|l|c|c|c|c|}
\hline \multicolumn{1}{|c|}{ Site } & \multicolumn{1}{|c|}{ Period } & Months & $\begin{array}{c}\text { Total } \\
\text { Miles }\end{array}$ & $\begin{array}{c}\text { Avg. Monthly } \\
\text { Miles/Bus }\end{array}$ & Availability \\
\hline VTA & March 2005-July 2006 & 17 & 40,429 & 793 & $58 \%$ \\
\hline SunLine & January 2006-November 2006 & 11 & 19,208 & 1,746 & $61 \%$ \\
\hline AC Transit & April 2006-November 2006 & 8 & 27,065 & 1,128 & $77 \%$ \\
\hline
\end{tabular}

\section{Fuel Economy}

Figure 6 shows the diesel equivalent fuel economies for the fuel cell and baseline buses at each of the three sites during the evaluation period of the last published DOE/NREL evaluation report for each site. At the VTA site, the fuel economy of the fuel cell buses was $12 \%$ lower than that of the diesel baseline buses. This result is significantly different from those at the other two sites because the VTA fuel cell buses do not incorporate a hybrid configuration and do not benefit from regenerative braking.

At SunLine, the baseline buses are CNG powered. The fuel economy of the fuel cell buses was $149 \%$ higher than that of the baseline buses, on an energy equivalent basis. At the AC Transit site, the fuel economy of the fuel cell buses was $67 \%$ higher than that of the diesel baseline buses. The fuel economy shown in the figure is slightly different from that reported in the DOE/NREL evaluation report because, after the report was completed, an analysis determined that the fuel economy calculation should not include hydrogen vented for taking the buses into the maintenance facility. That correction has been incorporated here.

\section{Hydrogen Dispensing}

Table 9 shows the hydrogen dispensing experience for each of the three sites during the evaluation period documented in the DOE/NREL evaluation reports. The average fills reflect the fuel economy of the fuel cell buses at each site. The buses with the lowest fuel economy (VTA) had the largest fills. For the average fill rate, the VTA station was highest. The SunLine station fueling rate was not available from the evaluation report. Average fill times for the three sites were 16 to 20 minutes. 


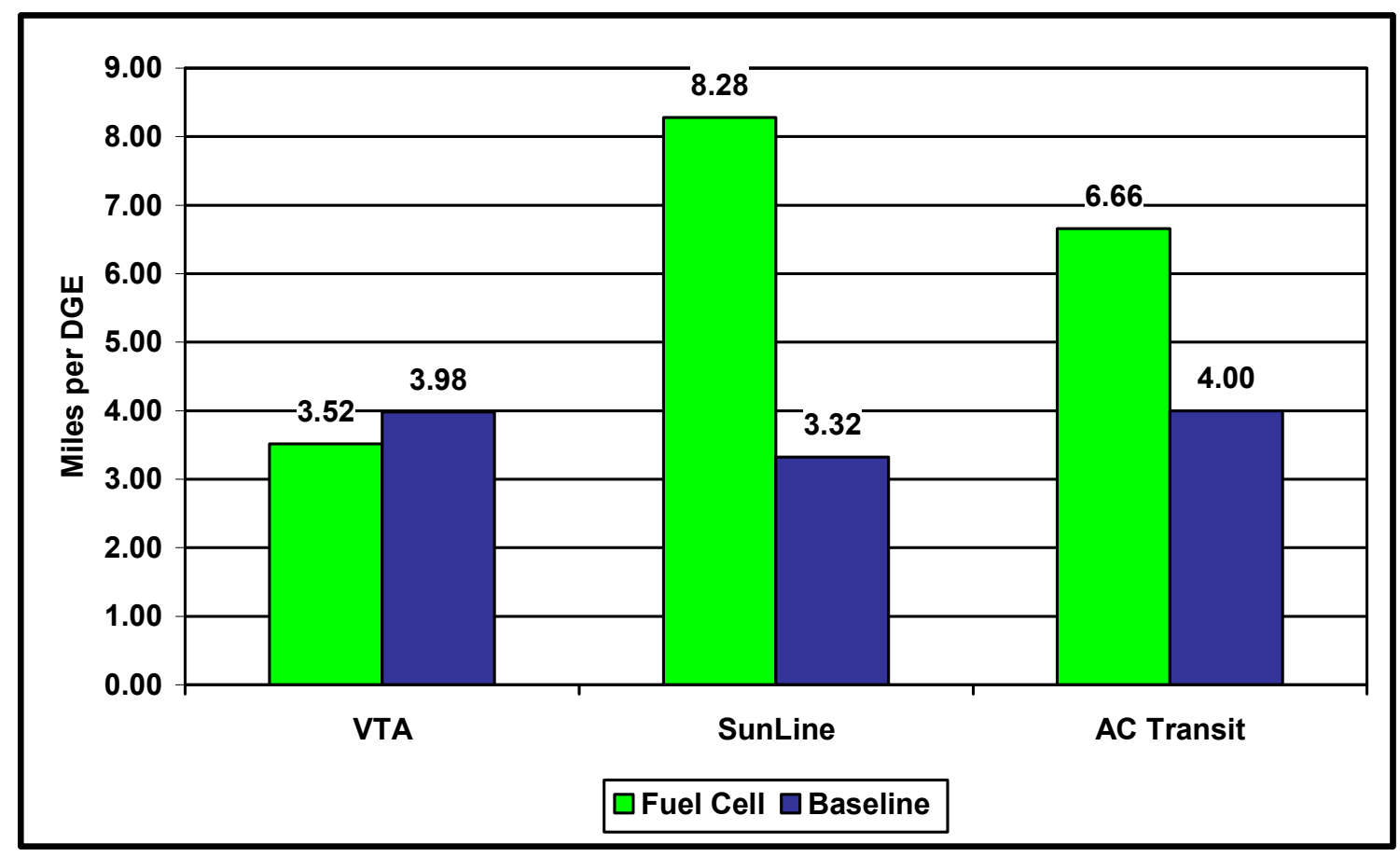

Figure 6. Diesel gallon equivalent fuel economies for fuel cell and baseline buses, by site

Table 9. Hydrogen Dispensing Experience for the Evaluation Period

\begin{tabular}{|l|l|c|c|c|c|c|}
\hline \multicolumn{1}{|c|}{ Site } & \multicolumn{1}{|c|}{ Period } & Months & $\begin{array}{c}\text { Total } \\
\text { H2 } \mathbf{( k g )}\end{array}$ & $\begin{array}{c}\text { Avg. Fill } \\
\text { (Kg/fill) }\end{array}$ & $\begin{array}{c}\text { Avg. Fill Rate } \\
\text { (kg/min) }\end{array}$ & $\begin{array}{c}\text { Avg. Fill } \\
\text { Time (min) }\end{array}$ \\
\hline VTA & March 2005-July 2006 & 17 & 14,024 & 30.9 & 1.93 & 16 \\
\hline SunLine & January 2006-November 2006 & 11 & 2,649 & 16.3 & N/A & 20 \\
\hline AC Transit & April 2006-November 2006 & 8 & 4,693 & 21.8 & 1.35 & 16 \\
\hline
\end{tabular}

\section{Roadcalls}

A roadcall (RC) or revenue vehicle system failure (as it is named in the National Transit Database) is defined as a failure of an in-service bus that causes the bus to be replaced en route or causes a significant delay in schedule. For this discussion, only the RCs for propulsionrelated systems are examined. In the DOE/NREL reports, the propulsion-related systems include transmission; nonlighting electrical (ignition, charging); air intake; cooling; exhaust; fuel; engine; and electric propulsion. In general, the three sites had similar propulsion-related RC rates, and these rates are generally a factor of 10 lower than those of typical baseline transit buses, which are around 10,000 miles between RCs (MBRC) for propulsion-related systems.

- VTA: 919 propulsion MBRC

- SunLine: 1,130 propulsion MBRC

- AC Transit : 1,230 propulsion MBRC 


\section{Site Implementation Experiences}

Current and planned demonstrations of fuel cell and hydrogen-powered transit buses focus on the use of field validations to help make the new technologies ready for transit agencies to put into service. For the three sites described in this report, the demonstration has been completed or is in the process of being completed by the transit agencies with support from the manufacturers. The implementation activities in these demonstrations can be described in terms of the following 10 general topic areas and are discussed in greater detail in this section:

- Funding Availability

- Infrastructure Needs and Design

- Vehicle Availability and Performance

- Manufacturer Support

- Emergency Response and Building Codes

- Fuel Availability and Fueling Capability

- Fleet Personnel and Management (at all levels)

- Public Awareness and Acceptance

- Data Collection, Analysis, and Reporting

\section{Funding Availability}

As with any advanced technology demonstration, estimating a budget and procuring sufficient funding are some of the biggest challenges faced by the transit industry. Agencies need to plan for purchasing the buses, installing the hydrogen infrastructure, modifying maintenance facilities, training staff, and potentially adding staff to operate and maintain the buses. All of this is in addition to the agency's standard operating budget. The three evaluation sites have each faced challenges in gathering the necessary funding, but they have achieved success through a variety of sources, including these:

- The federal government (FTA, DOE, and the Department of Defense)

- State government (CARB, the California Energy Commission, and Air Quality Management Districts)

- Local government

- Manufacturers and fuel providers (cost sharing)

- Participating transit agencies

Most U.S. transit agencies are public entities funded by a combination of federal, state, and local government. Fare box revenue is a small portion of each agency's budget. Capital equipment, such as buses, is funded up to $80 \%$ by federal funds through the FTA. These funds are appropriated each year in the congressional budget. All transit agencies must compete for these limited dollars. Table 10 provides the average cost of a bus in the United States, by type. At the current stage of the technology, a fuel cell bus is still an order of magnitude more costly than a 
standard diesel bus is. Continued development and optimization are necessary to help reduce this cost.

Table 10. Average Purchase Cost for Transit Buses

\begin{tabular}{|l|c|}
\hline \multicolumn{1}{|c|}{ Technology } & Approximate Cost* \\
\hline Standard 40-ft diesel bus (low floor) & $\$ 328,000$ \\
\hline CNG bus (40-ft, low floor) & $\$ 395,000$ \\
\hline Hybrid bus (40-ft, low floor) & $\$ 483,000$ \\
\hline Hybrid shuttle bus (22-ft) & $\$ 284,000$ \\
\hline Battery electric shuttle bus (22-ft) & $\$ 197,000$ \\
\hline Electric Trolley Bus (40-ft) & $\$ 850,000$ \\
\hline Fuel cell bus & $\$ 3$ million \\
\hline
\end{tabular}

Issues encountered by these demonstration sites included the following:

- These fuel cell transit buses are demonstration vehicles; however, the funding from FTA can come from the standard capital purchasing for buses or from a research and development account. One of the demonstration sites received funding from the FTA standard capital purchasing account, so each bus is expected to be operated for the minimum life of 12 years. These buses must be kept until the 12 years are completed, even if they are not operated.

- All three demonstration sites have struggled to ensure that funding will be made available from various sources. To manage resource needs, the transit agencies have at times paid for portions of the demonstrations out of their own discretionary funding as a stop-gap measure while waiting for additional funding. Multiple funding sources makes it difficult to manage all the reporting and contractual requirements.

\section{Infrastructure Needs and Design}

This section addresses the need for upgrades or new construction of maintenance facilities, bus washes, and fueling stations. The safety systems required for these infrastructure designs is also included here. At this stage, it has usually been extremely difficult to obtain verified, complete performance data from manufacturers for project and budget planning purposes (from the transit agency's perspective); the data are often unavailable to protect the manufacturer's intellectual property.

To support these demonstration projects, each evaluation site has added hydrogen fueling stations and added or modified maintenance facilities. Because hydrogen infrastructure is in the early stage of development, a precedent for building stations has not yet been established. Each added station is unique and has taken various approaches to producing and dispensing hydrogen.

Issues encountered by the demonstration sites included the following:

- Hydrogen sensors can be too sensitive and can be set off by other activities in the area. There are also issues of calibration, maintenance, and availability of replacement parts. 
The design of these sensors continues to change, which makes older versions obsolete and unavailable.

- There are few choices among manufacturers and designs, as well as a general lack of detailed information about the limited quantity of production equipment being used. This is true for fueling stations and buses alike.

- Sizing the fueling stations has been a costly issue that can result in venting fuel if there is not enough hydrogen storage. If the fueling station is using cryogenic fuel, there can be significant boil-off and venting, based on how much fuel is used.

\section{Vehicle Availability and Performance}

Fuel cell vehicle technologies are available today in the appropriate sizes and performance levels required for the planned demonstrations. Fuel cell buses demonstrated in the United States to date have proven to perform similarly to, or better than, conventional buses. Operators report noticing smooth, fast acceleration, which can be an advantage when pulling away from a bus stop into heavy traffic; this is also a general comment for most electric/hybrid bus designs. Fuel cell buses have been operated on bus routes with varying speeds, terrain, and traffic conditions, and they performed well under all these conditions.

The fuel cell propulsion systems are also much quieter than their diesel and CNG counterparts. In fact, the reduced engine noise has caused operators and passengers to notice the noise levels of auxiliary components, such as air conditioners. Manufacturers are currently investigating newer component designs to reduce these noise levels as well.

The three evaluation sites acquired buses through standard transit procurement procedures. These procurements were a first in the U.S. transit industry; earlier projects were all short-term demonstrations led by the manufacturers with buses they owned. A request for proposals to the industry elicited very few responses, which limited the choices for the agencies involved. As interest in fuel cell buses has increased, more manufacturers are developing products that are designed to meet various transit agency needs.

Issues encountered by the demonstration sites included the following:

- In the early stages of planning fuel cell bus demonstrations, product availability was a challenge. Very few manufacturers were ready to test a fuel cell bus, and the ones that had developed fuel cell buses already had several projects to monitor and support. Added projects would mean stretching already taxed resources and result in a higher risk.

- Agencies also reported a difficulty in getting complete, verified performance data on the buses to enable accurate project budget planning. At this early stage in development, manufacturers are reluctant to release this information to protect intellectual property rights or competitive market positioning.

- Fuel cell buses are heavier than conventional buses, mainly because of the added weight of the hydrogen fueling system. Current-generation fuel cell buses can be as much as $8,000 \mathrm{lb}$ heavier than a typical diesel bus. This must be considered when planning service for the buses. The added weight limits the number of passengers legally allowed to be 
standing on the bus; current-generation fuel cell buses can carry 38 fewer standing passengers than conventional diesel buses. This could be an issue during peak service and on routes that are heavily used.

- Because of hydrogen storage on the roof, fuel cell buses are also taller than a typical diesel bus is; current-generation models are as much as $2 \mathrm{ft}$ taller. This has necessitated facility modifications for some agencies, such as added clearance for bus washes. Some fleets have also experienced problems with low-hanging tree branches along bus routes. Operators inexperienced with the added height have reported feeling some difference in handling (for example, a feeling that the bus might tip over, especially during sharp turns).

- There have been some issues with the Buy America clause in purchasing these fuel cell buses with FTA capital funding.

\section{Manufacturer Support}

This section addresses warranty support for vehicles and infrastructure, plus other issues such as provision of manuals, training materials, and staff training; parts availability; and troubleshooting availability. All three demonstration sites reported excellent technical support from the manufacturers participating in their demonstrations. For two of the demonstration sites, the fuel cell manufacturer sent a technician/engineer to work at the site for the initial 24-month demonstration. In the case of the AC Transit site, ISE Corp. also sent an engineer to work at the site for the demonstration period. SunLine has had access to the technician/engineers that have been working at AC Transit, but they have come to SunLine only when necessary.

Training for operators and maintenance for all three sites has been provided by the manufacturers. Generally, maintenance troubleshooting has been done by the manufacturer's staff. At VTA, two mechanics were assigned to work with the Ballard technician to learn to troubleshoot and perform scheduled and unscheduled maintenance on the buses and fuel cell propulsion systems. Now that the VTA fuel cell buses are out of warranty, these two mechanics do all of the maintenance on these buses, contacting Ballard only for on-demand technical advice and troubleshooting.

In regard to fueling facilities, VTA has had on-demand support from Air Products for maintenance of its fueling station. AC Transit has had Chevron staff on-site, not only to operate and maintain the fueling station but also to fuel the buses. This has been changing as AC Transit staff are trained to fuel the buses, through a certification process that Chevron developed to ensure that AC Transit staff are qualified. SunLine owns its station and fueling equipment and has been fueling hydrogen for some time for several other projects.

Hydrogen fuel is produced by a commercial reformer unit for which SunLine provides warranty work, with support from HyRadix. SunLine's work and parts costs are reimbursed.

Issues encountered by the demonstration sites included the following:

- Some very early issues concerned the availability of parts for the fuel cell buses. Difficulties have included supplier quality control issues, components damaged during 
shipping, and extra time needed for parts from distant locations. In some cases, parts failed that were not expected to fail.

- At times during these demonstrations, there have been some challenges in getting access to maintenance information in a timely fashion. In general, it has been a slow process to prepare and train transit agency mechanics for full maintenance of these fuel cell buses and propulsion systems. There has been concern about access to proprietary software and computers for maintaining the fuel cell buses once the demonstration period has ended. The manufacturers and transit agencies are working through these issues.

\section{Emergency Response and Building Codes}

The use of this new equipment requires sharing safety information on an ongoing basis with fleet staff, regional area emergency responders, and codes enforcement officials. Familiarity, "comfort level" and trust are critical for smooth and safe operation.

Over the last few years, several hydrogen fueling stations have been designed, constructed, and operated to fuel the buses in U.S. demonstration projects. The stations have been operated safely with very few incidents, none causing injury or excess damage. Despite the success of these early projects, hydrogen infrastructure continues to be one of the biggest challenges for demonstration fleets. The ability to gain permits for new stations is hampered by the lack of standardization and differing requirements (and comfort levels) within various jurisdictions.

Each evaluation site reported some level of difficulty getting permits for the stations; they noted that early involvement and good communication with all parties involved can speed up the process. All three sites reported that including building code and emergency response officials as soon as possible when starting these projects is essential to success. Because SunLine already had hydrogen on site, it had no difficulty with permitting for the station upgrade.

Issues encountered by these demonstration sites included the following:

- One of the sites reported significant problems early on with false hydrogen leak alarms from the fueling station. This took a significant amount of time at first to figure out what was wrong technically; in the meantime, local emergency responders became more concerned about the safety of the fueling station. Significant work with the emergency responders was also required to determine appropriate emergency procedures, so that the level of response would not be higher than necessary, and to reduce the amount of inconvenience to neighbors. It was also important to determine what the restart process would be for the station if an emergency shutdown occurred.

- There are few hydrogen dispensing stations in the United States, and emergency responders' experience with those stations (and buses) is minimal. There is a significant need to provide familiarization training for emergency responders; this training is usually given by the transit agency. Emergency responder agencies have a significant number of staff members that rotate in and out of various locations, so providing familiarization training to all emergency responders that might be called to the transit agency can be rather daunting. The transit agency needs to plan and establish a continuous familiarization training program from the very beginning of the demonstration project. 


\section{Fuel Availability and Fueling Capability}

This section addresses issues associated with producing hydrogen on site, as well as the equipment required for production, and providing an on-site or nearby fueling station or, barring that, delivery of fuel to the site. Also discussed are the availability of the fuel, maintenance of the fuel delivery system, and backup plans for the fuel source, i.e., if fuel is unavailable or the fueling station is unavailable for service.

Most hydrogen fueling stations are capable of filling a bus at approximately $2 \mathrm{~kg}$ per minute, and a full fill typically takes from 10 to 20 minutes. Each project has reported a high rate of availability for the station, in part because of the redundancy of systems and the availability of on-site maintenance staff for troubleshooting and repair.

Issues encountered by the demonstration sites included the following:

- One demonstration site has an open, public access fuel station that includes hydrogen. This public access fueling station is located just outside the bus operating facility. Because hydrogen fueling stations are few, the need for public access stations has been an ongoing issue. However, for reasons of public safety, it is not feasible to have a public fueling station or even public access to a station located within a bus operating depot.

- One issue concerned the need for a high-speed, high-volume fueling protocol. The only protocol that currently exists is one designed for light-duty vehicles with a much smaller tank than those in the fuel cell buses. This caused some delay for one site in terms of being able to use high-speed fueling. Work is underway to consider a standard fueling protocol for the buses.

- Proper sizing of the fueling station is extremely important for the demonstrations to be cost effective. Planning for the demonstration needs to consider a station at least large enough for currently planned vehicles as well as potential future vehicles. In the case of liquid fuel, a storage tank that is too large for a planned demonstration can waste a tremendous amount of fuel during boil-off and venting.

- Some manufacturers are new to the transportation industry and do not fully understand the need for a quick response to problems with the fueling station. In one case, the transit agency added penalty clauses for the unavailability of hydrogen fuel, similar to those that have been used with CNG fueling suppliers. This type of arrangement needs to be balanced with cost.

- At all three sites, tracking hydrogen fuel production and the actual cost of the fuel dispensed has been a challenge. Much of the data are protected by agreements with the manufacturers. Also, there are issues associated with being able to submeter electricity and water use for only the fueling station. The station designs are new and somewhat experimental for a transit bus application.

\section{Fleet Personnel and Management}

This area includes training, the steep learning curve for staff, and the process of the fleet staff and management at all levels taking ownership of the new technology demonstration, which involves working with the manufacturer and warranty issues. Many times, this process requires 
several fleet champions to bridge the gap between what fleet personnel know and are comfortable with and what actually needs to be done to keep the demonstration vehicles and equipment operating - many times, while waiting for the manufacturer's staff to become available to help.

On the whole, experiences at these three sites have been excellent in regard to support from management and maintenance staff. Training has been provided to most, if not all, of the transit agency's staff at locations where the fuel cell buses have operated. Operations staff have been extremely supportive throughout the entire process. Successful training programs have been established and conducted; these include basic hydrogen familiarization for all transit staff, operator training for bus drivers, maintenance and repair training for mechanics, and first responder safety and emergency procedures to local fire officials and emergency responders. Transit agencies that have experience with research projects appear to have an advantage in integrating these types of technology demonstrations.

Issues encountered at the demonstration sites included the following:

- Experiences at the three demonstration sites show that union representatives were involved and provided good support. However, it is clear that these relationships are critical, so early involvement of the representation management staff is essential for the long-term success of a demonstration both currently and in the future.

- Some issues arose concerning ongoing training activities by the manufacturers and transferring the training responsibilities to transit agency staff as soon as possible.

- A specific issue that occurred at one site was an issue of creating special work blocks for the demonstration fuel cell buses. Work blocks that were created did not permit the operators to work the extra hours that other work assignments allowed. This caused some concerns about obtaining interest in fuel cell buses among experienced operators; however, this did not become a major issue. Experienced operators were still extremely interested in this new technology.

\section{Public Awareness and Acceptance}

These early demonstrations are meeting an important need to increase the public's awareness of hydrogen and fuel cell technologies. Transit buses have the potential to reach large numbers of the public. In addition to helping to educate transit riders, the buses are essentially traveling advertisements for the technology. Each evaluation site participated in multiple events and provided tours of facilities and buses to a wide variety of people. Groups from around the world with an interest in fuel cell buses have visited each fleet to view the technology and share results and experiences. Many of the buses also have onboard displays that describe the project and provide basic explanations of how the technology works. Handouts describing the project and technology were also developed to help educate the public. Each demonstration project reports observing a high level of public interest in its area.

Issues encountered by the demonstration sites included the following:

- At each demonstration site, increasing interest in the technology resulted in requests for multiple events and tours. Participation takes a bus out of service, however, and requires 
both the transit agency's and the manufacturer's staff to put in additional time and effort. This public access is important, so planning should include the resources needed to ensure that these investments can be made.

\section{Data Collection, Analysis, and Reporting}

The greatest value of demonstrating these vehicles and infrastructure can be achieved only by validation through data collection, analysis, and complete reporting of experiences so that policy makers and other fleets can benefit from them. This validation process is also extremely helpful to the transit agency demonstrating the technology. In many cases, manufacturers will collect their own performance information and make adjustments to their product; however, only the fleet operator has access to project data and results on implementation and fleet operation.

Demonstration project members at all three evaluation sites have been extremely willing participants and have noted the importance of having DOE/NREL conduct third-party evaluations and reporting. Interested federal and state agencies have already used the results to help plan their rules and incentive programs.

Issues encountered by the demonstration sites included the following:

- Much of the detailed operations and maintenance data from these demonstrations have been protected to some level through nondisclosure agreements between the transit agencies and the manufacturers. This has caused some problems with sharing important and timely results with others in the transit industry. There must be a balance between the need for the data and results and the manufacturer's intellectual property and market competitive position.

- For multiple transit agencies to have a positive experience with these new technologies, it is critical to share others' experiences and data. Important lessons need only be learned once if experiences can be shared. There must be more sharing opportunities between transit agencies operating demonstrations and those interested in planning their own demonstrations. As noted previously, these opportunities should be balanced against the needs of manufacturers to protect their intellectual property and market position. 


\section{Industry's Needs for Continued Successful Implementation}

The next stage in demonstrating new and advanced technologies such as these fuel cell and hydrogen-powered propulsion systems is to focus on optimization for cost-effective implementation in fleets. Specifically, the following issues need to be addressed:

- Cost - The number-one priority for these technologies before they are fully deployed is to optimize the initial cost of purchasing the vehicles and infrastructure; this includes the cost to install infrastructure, deliver fuel, and operate and maintain vehicles and infrastructure alike.

- Performance and reliability — Significant work is required to ensure that these new technologies can operate in normal service; there is a need to minimize the negative and maximize the positive differences between the new and the conventional technologies.

- Fleet personnel awareness and training - There is a need to focus on full implementation and integration within a fleet and fully train all relevant personnel.

- Durability - One of the few ways to control operations and maintenance costs is to address durability and to analyze the overall operation from a life-cycle-cost perspective.

- Continued data collection, analysis, and reporting - This activity must continue and must be widely available and useful to policy makers and fleets.

Current demonstration projects are not yet at this stage. However, much of the decision-making and planning by the partners involved in these demonstrations is focused on how to move forward into the optimization stage.

For fuel cell transit bus development and implementation to move ahead to deployment and commercialization, several activities need to continue and several more need to be added. Continued support and funding for existing activities include the following:

- Both new and existing demonstrations must continue and be supported. There is a need for more understanding of durability and ongoing introduction issues with these technologies. Also, existing investments in the demonstrations must not be forgotten or lost. These activities require significant resources that cannot easily be replaced. Longer term durability and reliability issues beyond the warranty period also must be addressed.

- Targeted research must continue, especially in the areas of energy storage, hydrogen production and availability, electric accessories development, overall system weight reductions, and detection sensor reliability, among others.

- Third-party evaluations and dissemination of evaluation information are critical. Continued use of a standardized protocol for those evaluations is also necessary.

- Development of appropriate training and awareness materials must continue.

- Work must continue on completing the development of codes and standards as well as on continuing to support awareness activities for codes officials. 
These additional activities should be considered for continued implementation success:

- A strategic plan or roadmap should be developed with objectives, targets, and timelines for a larger scale implementation program that includes 50 to 100 transit buses; this should include more than one fuel cell type and bus manufacturer as well as demonstrations at multiple sites with varying operating conditions. This program needs to go beyond current plans for DOT/FTA demonstration programs such as the NFCBP. This type of large-scale implementation program will require significantly more federal and state funding than the $\$ 49$ million provided under the NFCBP.

- There is a need to significantly increase industry's access to data and detailed technology information, for planning demonstrations and deployment activities as well as assessing progress.

- For these additional activities to be successful there is a need for several more willing and committed fleet partners. 


\section{Acronyms and Abbreviations}

\begin{tabular}{|c|c|}
\hline AC Transit & Alameda-Contra Costa Transit District \\
\hline APTA & American Public Transportation Association \\
\hline CARB & California Air Resources Board \\
\hline $\mathrm{CNG}$ & compressed natural gas \\
\hline CTE & Center for Transportation and the Environment \\
\hline CUTE & Clean Urban Transport for Europe \\
\hline DGE & diesel gallon equivalent \\
\hline DOE & U.S. Department of Energy \\
\hline DOT & U.S. Department of Transportation \\
\hline ECTOS & Ecological City Transport System \\
\hline $\mathrm{FC}$ & fuel cell \\
\hline $\mathrm{FCB}$ & fuel cell bus \\
\hline $\mathrm{FCV}$ & fuel cell vehicle \\
\hline $\mathrm{ft}$ & feet \\
\hline FTA & Federal Transit Administration \\
\hline GGT & Golden Gate Transit \\
\hline GVWR & gross vehicular weight rating \\
\hline HFCIT & Hydrogen, Fuel Cells, \& Infrastructure Technology \\
\hline HHICE & hydrogen hybrid internal combustion engine \\
\hline $\mathrm{hp}$ & horsepower \\
\hline in & inches \\
\hline $\mathrm{kg}$ & kilogram \\
\hline $\mathrm{kW}$ & kilowatts \\
\hline $\mathrm{kWh}$ & kilowatt-hours \\
\hline $\mathrm{lb}$ & pounds \\
\hline MBRC & miles between road calls \\
\hline $\operatorname{mpg}$ & miles per gallon \\
\hline $\mathrm{mph}$ & miles per hour \\
\hline NAVC & Northeastern Advanced Vehicle Consortium \\
\hline NFCBP & National Fuel Cell Bus Program \\
\hline NRCan & Natural Resources Canada \\
\hline NREL & National Renewable Energy Laboratory \\
\hline PAFC & phosphoric acid fuel cell \\
\hline PEM & proton exchange membrane \\
\hline psi & pounds per square inch \\
\hline $\mathrm{RC}$ & road call \\
\hline RFP & request for proposal \\
\hline rpm & revolutions per minute \\
\hline \multirow[t]{2}{*}{ SAFETEA-LU } & Safe, Accountable, Flexible, Efficient \\
\hline & Transportation Equity Act: a Legacy for Users \\
\hline SamTrans & San Mateo County Transit District \\
\hline STEP & Sustainable Transport Energy for Perth \\
\hline UNDP-GEF & United Nations Development Program-Global \\
\hline & Environmental Facility \\
\hline
\end{tabular}


VTA

ZEB
Santa Clara Valley Transportation Authority zero-emission bus 


\section{REPORT DOCUMENTATION PAGE}

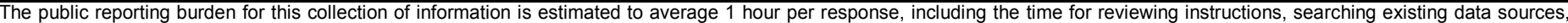

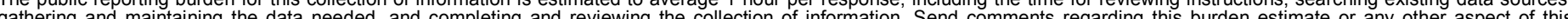

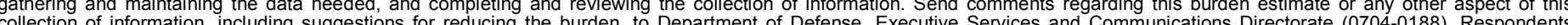

should be aware that notwithstanding any other provision of law, $n$

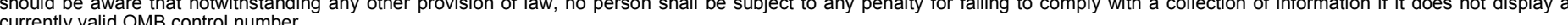

PLEASE DO NOT RETURN YOUR FORM TO THE ABOVE ORGANIZATION.

\begin{tabular}{l|l|l|l} 
1. REPORT DATE $(D D-M M-Y Y Y Y)$ & 2. & REPORT TYPE & 3. DATES COVERED (FrOm - TO)
\end{tabular}

September 2007

4. TITLE AND SUBTITLE

Fuel Cell Buses in U.S. Transit Fleets: Summary of Experiences and Current Status 5a. CONTRACT NUMBER

DE-AC36-99-GO10337

5b. GRANT NUMBER

5c. PROGRAM ELEMENT NUMBER

5d. PROJECT NUMBER

NREL/TP-560-41967

5e. TASK NUMBER

$\mathrm{H} 2708200$

5f. WORK UNIT NUMBER
7. PERFORMING ORGANIZATION NAME(S) AND ADDRESS(ES)

National Renewable Energy Laboratory

1617 Cole Blvd.

Golden, CO 80401-3393
8. PERFORMING ORGANIZATION REPORT NUMBER

NREL/TP-560-41967

9. SPONSORING/MONITORING AGENCY NAME(S) AND ADDRESS(ES)

10. SPONSOR/MONITOR'S ACRONYM(S) NREL

11. SPONSORING/MONITORING AGENCY REPORT NUMBER

12. DISTRIBUTION AVAILABILITY STATEMENT

National Technical Information Service

U.S. Department of Commerce

5285 Port Royal Road

Springfield, VA 22161

13. SUPPLEMENTARY NOTES

14. ABSTRACT (Maximum 200 Words)

This report reviews past and present fuel cell bus technology development and implementation in the United States.

15. SUBJECT TERMS

fuel cell bus; transit; bus evaluation; FTA

16. SECURITY CLASSIFICATION OF:
\begin{tabular}{|l|l|l|}
\hline $\begin{array}{c}\text { a. REPORT } \\
\text { Unclassified }\end{array}$ & $\begin{array}{c}\text { b. ABSTRACT } \\
\text { Unclassified }\end{array}$ & $\begin{array}{l}\text { c. THIS PAGE } \\
\text { Unclassified }\end{array}$ \\
& & \\
\hline
\end{tabular}

\begin{tabular}{|c|c|}
\hline $\begin{array}{l}\text { 17. LIMITATION } \\
\text { OF ABSTRACT }\end{array}$ & $\begin{array}{l}\text { 18. } \\
\text { OFUMBER } \\
\text { OFAGES }\end{array}$ \\
\hline UL & \\
\hline
\end{tabular}

19a. NAME OF RESPONSIBLE PERSON

19b. TELEPHONE NUMBER (Include area code) 